\begin{tabular}{|c|c|c|}
\hline & International Journal of Current Research in \\
Biosciences and Plant Biology & Volume $5 \bullet$ Number 6 (June-2018) • ISSN: 2349-8080 (Online) \\
\hline EXCELLENT \\
PUBLISHERS
\end{tabular}

Original Research Article

doi: $\underline{\text { https://doi.org/10.20546/ijcrbp.2018.506.003 }}$

\title{
First Record of Fourteen Basidiomycetous Macrofungi (Agaricomycetes) from Iraq
}

\section{Talib O. Al-Khesrajii ${ }^{1}$, Sara Q. Suliaman ${ }^{2 *}$ and Abdullah A. Hassan ${ }^{3}$}

${ }^{1}$ Department of Biology, College of Education for Pure Sciences, Tikrit University, Tikrit, Iraq

2Department of Biology, College of Sciences, Tikrit University, Tikrit, Iraq

32Department of Protection, College of Agriculture, Tikrit University, Tikrit, Iraq

*Corresponding author.

\begin{tabular}{|c|c|}
\hline Article Info & ABSTRACT \\
\hline Date of Acceptance: & \multirow{5}{*}{$\begin{array}{l}\text { The present study reports on macrofungi species collected from March } 2015 \text { to May } \\
2016 \text { in Amadiyah, Erbil and Suliamaniya districts (Northeast Iraq). In this studies } \\
\text { fourteen taxa (Agaricus bitorquis, Amanita fuliginea (Agaricaceae), Agrocybe aegerita, } \\
\text { Agrocybe praecox (Bolbitiaceae), Coprinopsis atramentaria, Coprinopsis strossmayeri } \\
\text { (Psathyrellaceae), Hymenogaster sp. (Hymenogastraceae), Inocybe glabripes, Inocybe } \\
\text { hystrix (Inocybaceae), Tricholoma scalpturatum (Tricholomataceae), Boletus luridus } \\
\text { (Boletaceae), Ganoderma adspersum, Polyporus arcularius (Polyporaceae) and Russula } \\
\text { delica (Russulaceae) belong to one division, eleven genera, nine families and four orders } \\
\text { were recorded for the first time in Iraq. }\end{array}$} \\
\hline 12 May 2018 & \\
\hline $\begin{array}{l}\text { Date of Publication: } \\
\text { 06 June } 2018\end{array}$ & \\
\hline Keywords & \\
\hline $\begin{array}{l}\text { Agaricomycetes } \\
\text { Basidiomycota } \\
\text { Fungal diversity }\end{array}$ & \\
\hline
\end{tabular}

\section{Introduction}

The most advanced group of fungi is the club fungi or Phylum Basidiomycota, which contains about 30,000 species, (37\% of the described species) (Kirk et al., 2001). Most macrofungi are included in Basidiomycota or Ascomycota (Mueller et al., 2007). Macrofungi can be epigeous or hypogeous, large enough to be seen with the naked eyes and can be picked by hand (Chang and Miles 1992). They mostly belong to different groups such as agarics, boletus, jelly fungi, coral fungi, stinkhorns, bracket fungi, puffballs and bird's nest fungi.

Agaricomycetes is a class under the Subdivision Agaricomycotina and the Division Basidiomycota, comprising 17 orders, 100 families, 1,147 genus and about 21,000 species, representing about fifth of the world's fungal species (Kirk et al., 2008) and $98 \%$ of the species known under the Agaricomycotina (Kirk et al., 2001). These fungi are very important as sources in medicine, industry, 
agriculture and bioremediation as well as it's role in natural cycling (Molina et al., 1993; Cowan 2001; Chang and Miles. 2004).

Amadiyah, Erbil and Suliamaniya provinces are located in the Northern of Iraq. The Kurdistan Region comprises parts of the three governorates of Duhok,Erbil and Suliamaniya. Kurdistan of Iraq covers about $40,000 \mathrm{Km}^{2}$ of Iraq. It is with a cold winter (December - March or April) and relatively high rainfall upwards to $800 \mathrm{~mm}$ and the mountains above approximately the $1800 \mathrm{~m}$ level are snowbound for several months and snows often falls in the valleys, while the summer though hot and dry, is comparatively of shorter duration (June to September) than on the other parts of Iraq (May to October). These factors contribute to richer biodiversity situation especially the floral components (Lahony, 2013). And because of the favorable climate and the type of vegetation, especially Quercus sp., Punica sp., Juglans sp. (Mati, 2009), Kurdistan of Iraq have a rich macromycota.

In the last few years, the progress of recording and describing macrofungi species in Iraq is evident, especially in northern Iraq (Al-Qaissi, 2014; Al-Khesraji, 2016; Suliaman et al., 2017; AlKhesraji et al., 2018) and in the western Iraq (Muslat and Owaid, 2015). However, many areas of the country with a great biodiversity remain unexplored and their mycota unknown.

\section{Materials and methods}

The macrofungi samples were collected from different locations in the Amadiyah $\left[37^{\circ} 05^{\prime} 33^{\prime \prime} \mathrm{N}\right.$ $43^{\circ} 29^{\prime} 14^{\prime \prime} \mathrm{E}$, elevation 3,900 ft $\left.(1,200 \mathrm{~m})\right]$, Erbil [36 $11^{\prime} 28^{\prime \prime} \mathrm{N} \quad 44^{\circ} 0^{\prime} 33^{\prime \prime} \mathrm{E}$, elevation $390 \mathrm{~m}$ $(1,280 \mathrm{ft})]$, and Sulaymania $\left[35^{\circ} 33^{\prime} 26^{\prime \prime} \mathrm{N}\right.$ $45^{\circ} 26^{\prime} 08^{\prime \prime} \mathrm{E}$, elevation $\left.882 \mathrm{~m}(2,895 \mathrm{ft})\right]$ districts of Iraqi Kurdistan during the period from March 2015 to May 2016. Habitats and habit were recorded in the study area. Samples were photographed in natural habitat and in laboratory. The fungal samples were carefully taken by gently lifting or dipping (not pulling) to avoid damage their bases
(Sibounnavong et al., 2008). Then samples were placed separately in paper bags and transfer to the laboratory for Macroscopic features (such as cap size, shape, color and surface texture; gills color, attachment to stipe (if present); stipe size, color and surface texture) and Microscopic features (including characters like basidia size and their spore number, spore shape, size and color and presence or absence of cystidia and their shapes and types) for diagnosis. Cotton blue in lactophenol was used for light microscopy. Fungal samples were identified according to field guides and relevant litretures (Dodg et al., 1934; Hongo, 1953; Ramsbottom, 1953; Hard, 1961; Pacioni and Lincoff, 1981; Quimion, 1982; Corner, 1984; Arora, 1986; Kuyper, 1986; Ryvarden et al., 1993; Christensen and Noordelos, 1999; Halling and Mueller, 2005; Kuo, 2005; 2006; 2008; 2015; Knudsen and Vesterholt, 2008; Ryberg et al., 2008; Ostry et al., 2011; Badalyan, 2011; O'Reilly, 2011; Phillips, 2013; Wood and Stevens, 2015). Samples were kept in the Department of Biology / College of Education for Pure Sciences / University of Tikrit.

\section{Results and discussion}

The chemical the survey of different localities of Amadiyah, Erbil and Suliamaniya districts (Northeast Iraq) fourteen Basidiomycota macrofungal species from 11 genera, 9 families and 4 orders were identified. These specimens are new to Iraq. Description, distribution, and edibility of the reported taxa are given below.

\section{Kingdom: Mycetae \\ Phylum: Basidiomycota \\ Class: Agaricomycetes \\ Order: Agaricales \\ Family: Agaricaceae \\ Species: Agaricus bitorquis (Quélet) Sacc.}

(Fig. 1).

Macroscopic features: Cap $36-120 \mathrm{~mm}$ broad, white, convex becoming broadly convex and yellowish in age, smooth with an enrolled margin to the inside; Gills free from the stipe, pink, dark 
reddish - brown at maturity; stipe $24-32 \times 37-40$ $\mathrm{mm}$, whiter, cylindrical, equal, thick, stout, smooth, central, solid with annulus; volva absent. Microscopic features: Basidium 7.5-8.75 $\mu \mathrm{m}$, 4spored; spores 5.5-7.0 $\times$ 5.0-6.5 $\mu \mathrm{m}$, elliptical, hyaline; cystidia cylindrical; many; clamp connections absent.

Solitary or gregarious in garden between grasses and under paving sheet, edible, Sami AbdulRahman district, March to April. A. bitorquis was reported from Argentina (Niveiro and Alberto,
2013), India (Farook et al., 2013) and Turkey (Sesli and Denchev, 2008). A. bitorqsduis is one of the most important edible fungi, as studies have shown that it contains 18 amino acids, including the essentials (Zakhary et al., 1983). And a high proportion of fatty acids (Öztürk and et al., 2011). One study referred to the accumulation of toxic heavy metals such as lead in their fruit bodies in polluted areas (Cocchia et al., 2006). Other studies such as Öztürk et al., (2011) have pointed to the functional roles of this species as antioxidant, anticholinesterase, and antibacterial.

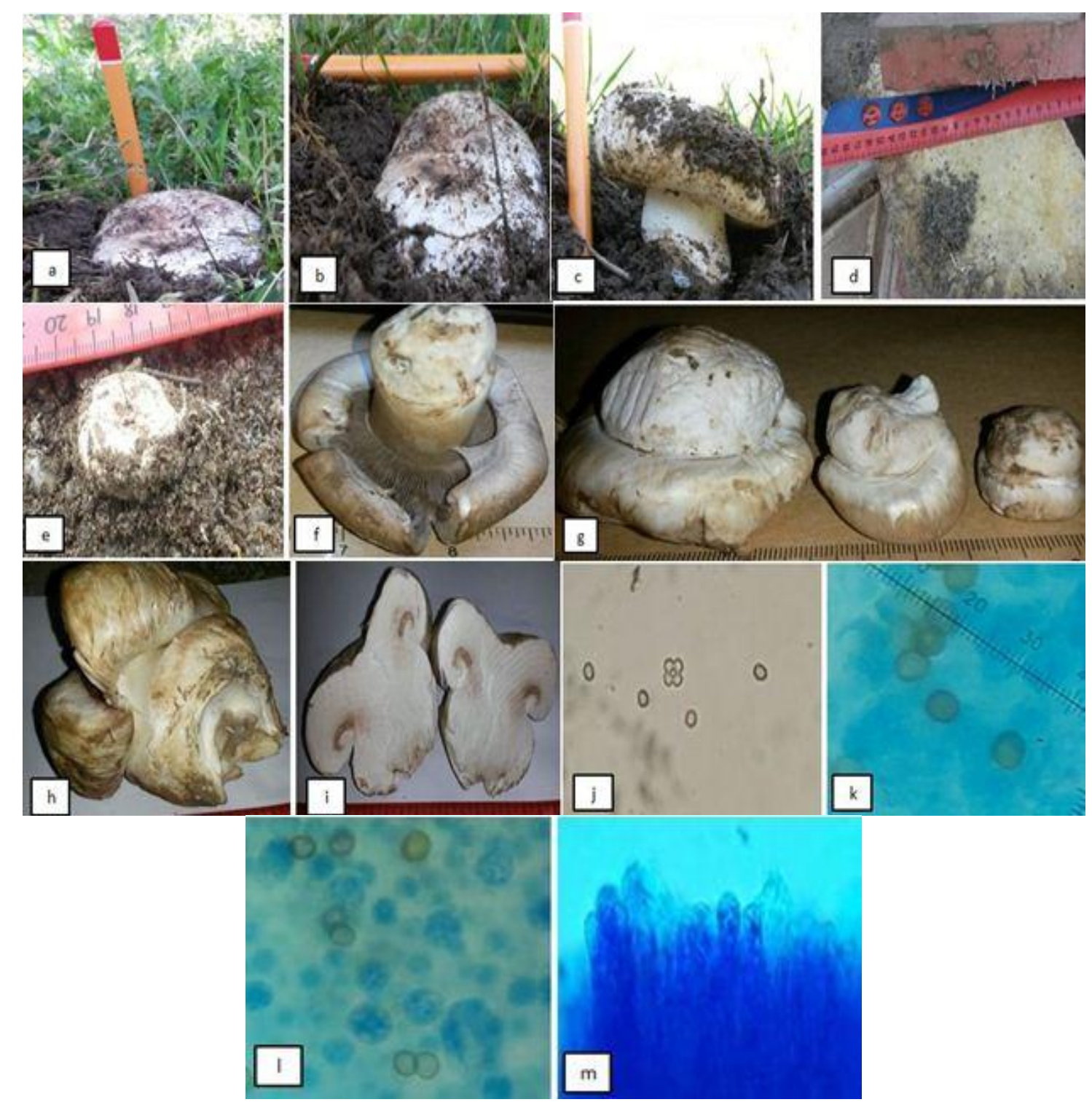

Fig. 1: A. bitorquis. a - c, in natural habitat between grasses; d, e, in natural habitat under paving sheet; f, g,h, general morphology in (lab); I, cross section of fruiting body; j, 4 spored basidia $(100 \times)$ in surface view; $\mathrm{k}, 1$, spores $(1000 \times)$; m, cystidia $(400 \times)$. 


\section{Family : Bolbitiaceae}

Species: Agrocybe aegerita (V. Brig.) Singer (= Cylocybe aegerita (V. Brig.) Vizzini) (Fig. 2)

Macroscopic features: Cap 15-40 $\mathrm{mm}$ broad, creamy, convex, flatted with age, smooth, cracked with wavy margin; gills attached to the stipe, slightly decurrent, creamy to brown; stipe 15-30 $\times$ 3-7 mm, creamy, cylindrical, smooth with short lacunate, bent, central, solid with superior ring which is thick, membranous, creamy; volva absent.

Microscopic features : Basidium 7.0-7.5 × 25-28 $\mu \mathrm{m}$, 4-spored; spores 7-13 $\times$ 4-7 $\mu \mathrm{m}$, elliptical, light yellowish brown; Cystidia: pleurocystidia $17 \times 8 \mu \mathrm{m}$, clavate, light yellowish brown; clamp connections present. Solitary or gregarious on the dead Populous sp. trees, unknown edibility, Hujran forest / Erbil district, Kalar / Suliamaniya, April to December. It was recorded in Colombia (Vasco-Palacios and Franco-Molano, 2013), Argentina (Niveiro and Alberto, 2013), India (Amandeep and Munruchi, 2015) and South America (Coimbra, 2015).

Several studies have demonstrated the effectiveness of the species in many biological events, including its anti-cancer effect, which is due to the presence of lectin, known as AAL (antitumor lectin) derived from the agro-organisms of the species Agrocybe aegerita (Zhao et al., 2003), as well as the role of lectin in many physiological processes (Sun et al., 2003). Lo and Cheung (2005) also demonstrated antioxidant efficacy associated with its total content of phenols.
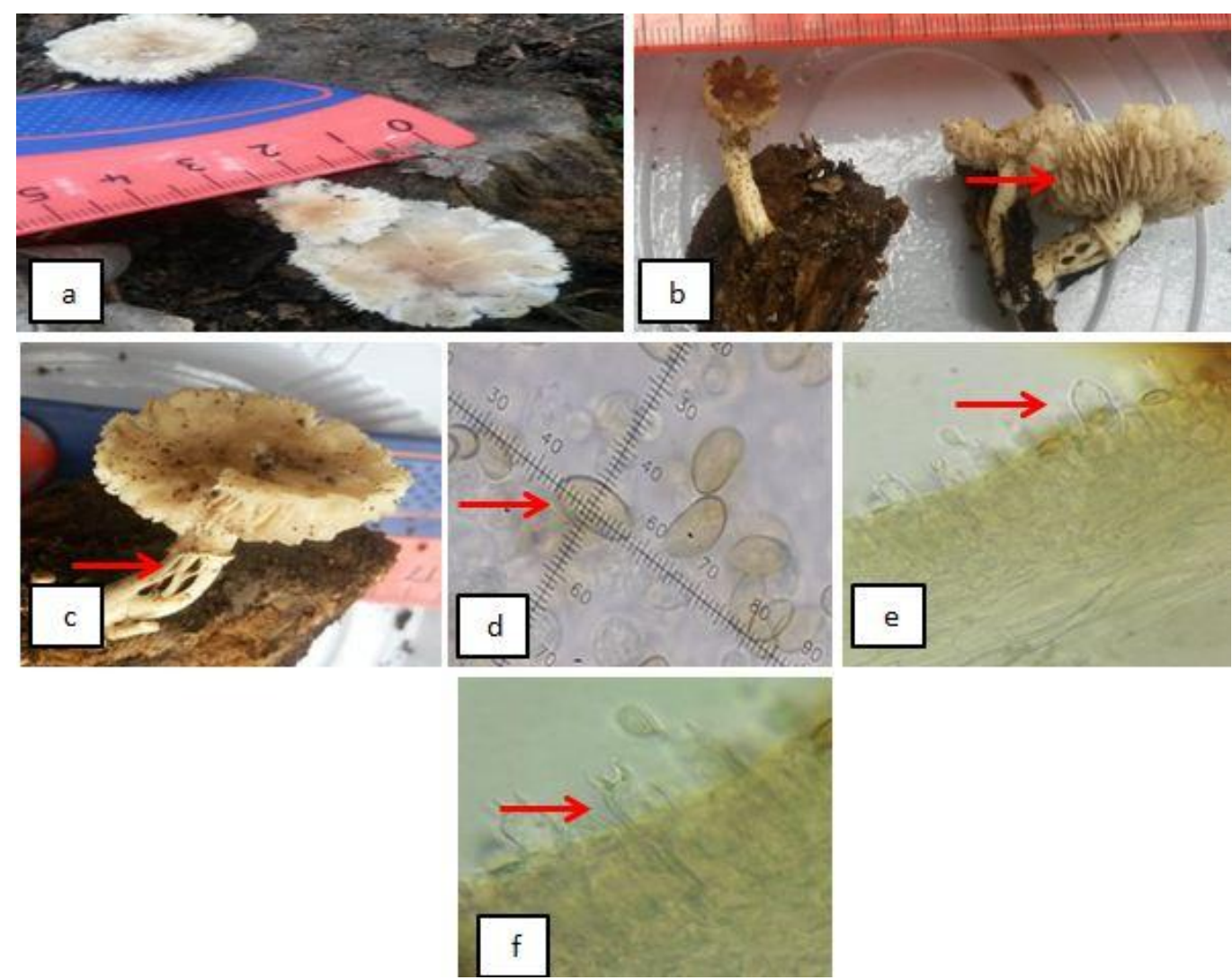

Fig. 2 : A. aegerita . a, in natural habitat; b, gills; c, short lacunate on the stipe; d, spores; e, cystidia (400x); f, basidium (1000x).

Species: Agrocybe praecox (Pers.) Fayod (Fig. 3)

Macroscopic features: Cap $40 \mathrm{~mm}$ broad, white to brown, turned into beige after the cut and to yellowish brown at the edges after being saturated with moisture. This is a distinguishing characteristic of species A. aegerita, convex, compressed slightly depressed in the center, 
smooth; Gills: connected to the stipe, light brown; stipe $61 \times 7 \mathrm{~mm}$, white to pale brown, cylindrical, curved, equal, lined longitudinal, central, solid with a ring and without a volva; Flesh : white turn its color into light brown after cutting.

Microscopic features: Basidium 8-9 x 4-6 $\mu \mathrm{m}, 4$ spored; spores $8-11 \times 5-7 \mu \mathrm{m}$, elliptical, light yellow, smooth; Cystidia: pleurocystidia 38-40 $\times$ 10-14 $\mu \mathrm{m}$, utriform; cheilocystidia similar to pleurocystidia; clamp connections present.
Solitary on the dead trees of Salix sp., edible, Heran / Erbil district, March to April. It was found in Turkey (Sesli and Denchev, 2008; Kaya, 2009), Iran (Karim et al., 2013), Argentina (Niveiro and Alberto, 2013), Colombia (Vasco-Palacios and Franco-Molano, 2013) and South America (Coimbra, 2015). Several studies have pointed to the importance of the Agrocybe praecox as an antibacterial, anti- inflammatory and anti-cancer (Suay et al., 2000; Shen et al., 2009; Albrechtova et al., 2012).

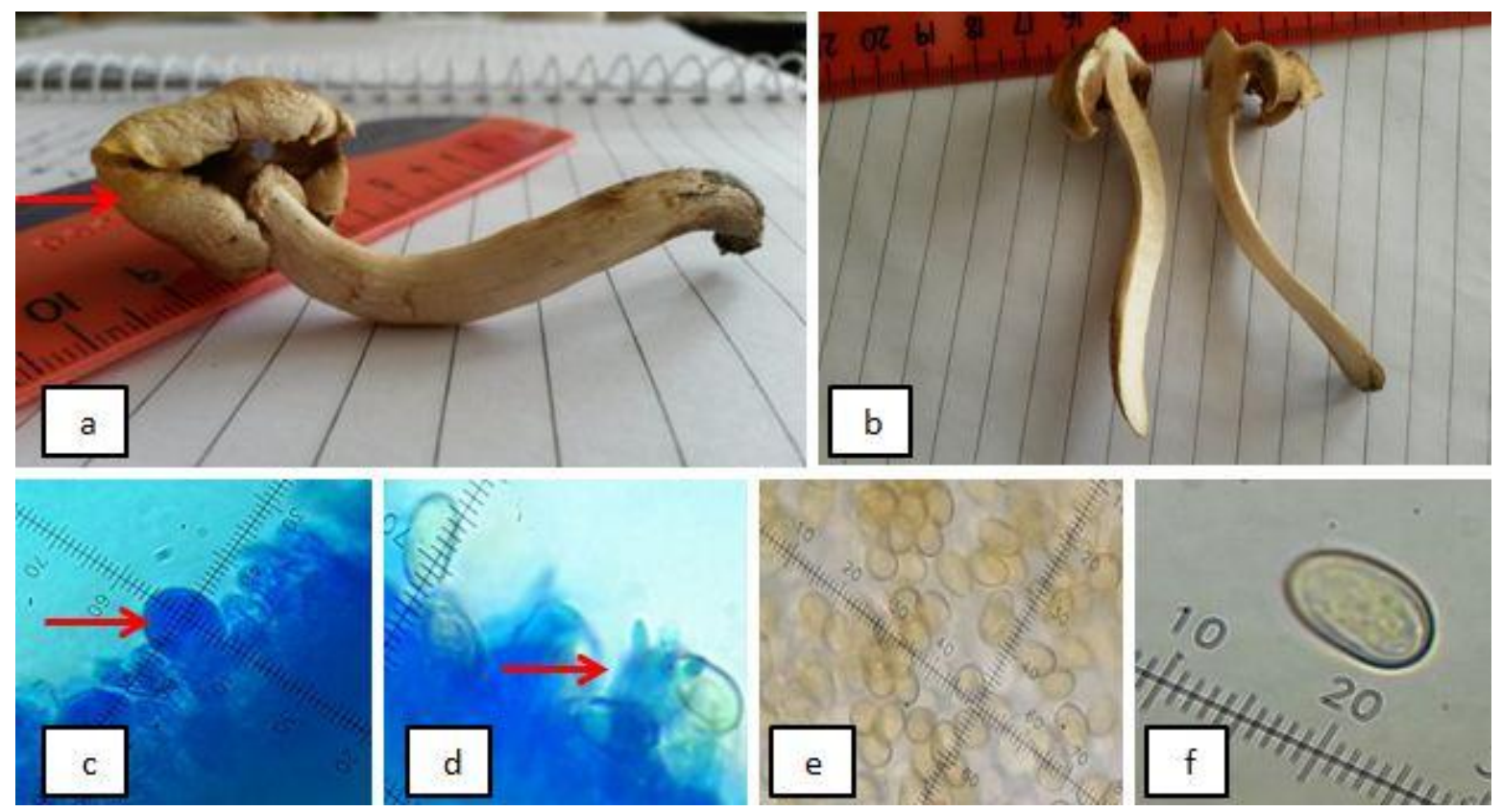

Fig. 3 : A.praecox. a, fruiting body of the fungus (Note yellowing the margin of the cap); $b$, longitudinal section of the fruiting body. c, cystidia (1000x); d, basidium (1000x); e, spores (400x); f, magnified spore $(1000 \times)$.

\section{Species: Amanita fuliginea Hongo (Fig. 4)}

Macroscopic features : Cap $119 \mathrm{~mm}$ broad, deep gray, light gray at edge, convex, smooth; Gills: free, white, large; Stipe $203 \times 31 \mathrm{~mm}$, white to gray, bulbous $35 \mathrm{~mm}$ broad, with ring; Volva: limbate, ends are free, a characteristic unique to some species of Amanita of the section Phalloideae (Zhang et al., 2004).

Microscopic features: Basidium 4-spored; spores 7.5-12.5 × $7.5-10.0 \mu \mathrm{m}$, globose or subglobose, hyaline, smooth; clamp connections absent. Solitary or gregarious in forest soil, unknown edibility,
Chuwarta / Suliamaniya district, April to May. It was registered as a new species in several East Asian countries (Zhang et al., 2010) such as Thailand (Sanmee et al., 2008) and China (Cai et al., 2014). Amanita fuliginea is a poisonous species that has caused many disasters in central China and is characterized by the presence of two types of cyclopptidic toxins, Amatoxin and Phallotoxin (Zhang et al., 2005; Chen et al., 2014). On the other hand, these two compounds are wiAdely used in biological research for the purpose of inhibition of RNA polymerase and inhibition of protein synthesis (Korn, 1982; Rebello and Ludescher, 1998). 

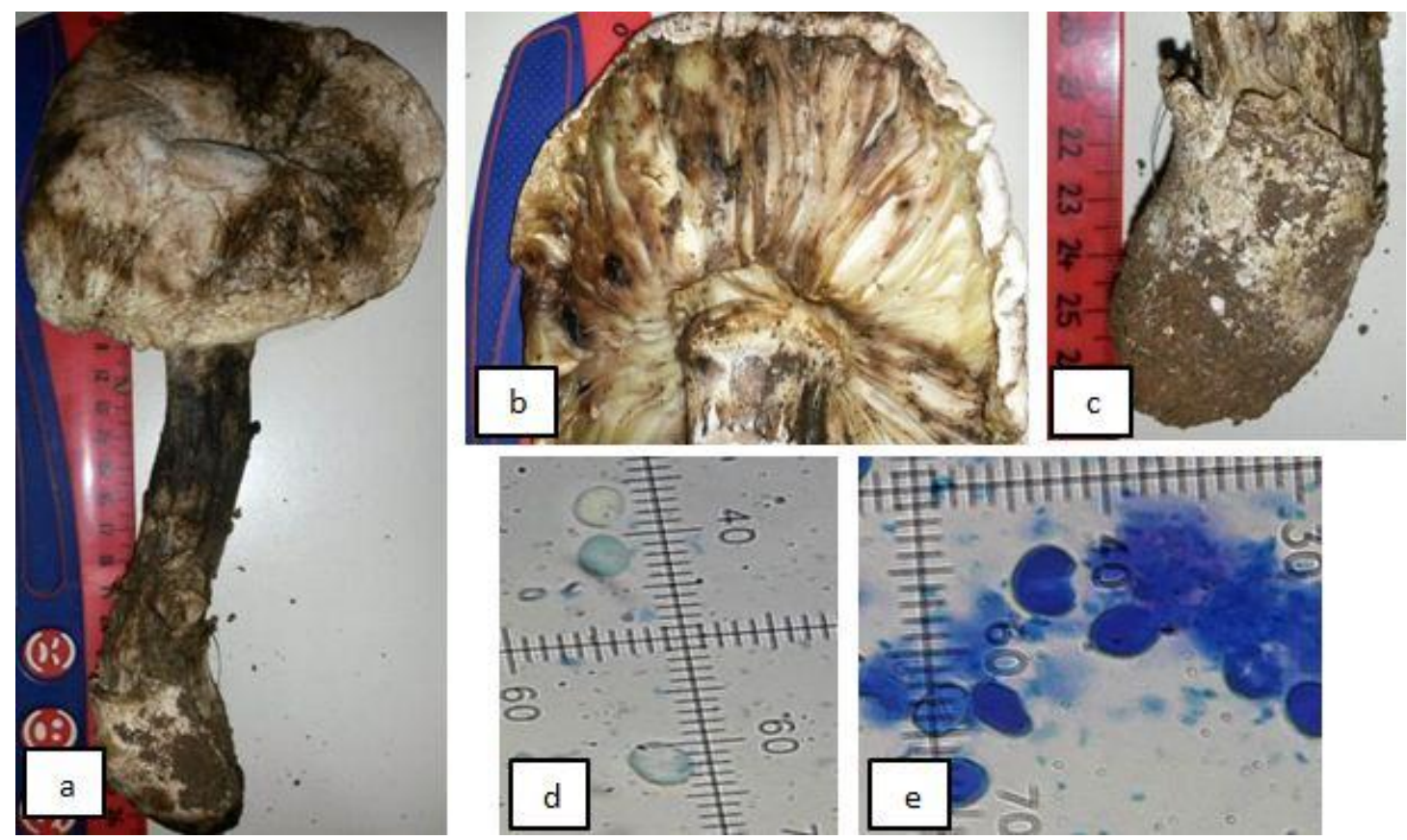

Fig. 4 : A. fuliginea. a, Fruiting body; b, cap; c, volva ; d ; e, spores (400x).

\section{Family: Psathyrellaceae}

Species: Coprinopsis atramentaria (Bull.: Fr.) Redhead, Vilgalys \& Moncalvo (=Coprinus atramentarius (Bull.: Fr.) Fries (Fig. 5)

Macroscopic features: Cap $26 \mathrm{~mm}$ broad, $18 \mathrm{~mm}$ height, brown, deep brown at center, conical, umbonate, stretch gray grooves to light black on cap surface covered by shiny white granules, irregular or torn edge; Gills: attached to the stipe, dark brown to black, crowded; stipe $48 \times 5 \mathrm{~mm}$, white, cylindrical, equal, smooth, hollow; ring and volva are absent.

Microscopic features: Basidium 7.5-8.0 $\mu \mathrm{m}, 4-$ spored; spore $6-8 \times 4-5 \mu \mathrm{m}$, elliptical, pore at the top of the spore, dark brown, touch; Cystidia: pleurocystidia and cheilocystidia $57 \times 20 \mu \mathrm{m}$, identical, utriform; clamp connections present.

Solitary among leaf litter in mixed forest, unknown edibility, Hujran forest / Erbil district, March to April. This fungus was collected from Turkey (Kaya et al., 2010; Sesli and Denchev, 2008), Bulgaria (Denchev and Assyov, 2010), Armenia (Badalyan et al., 2011). The species is characterized by its antibacterial activity due to its content of phenolic acids (Heleno et al., 2014) as well as its role as anti-cancer in promoting digestion and eliminating phlegm (Dai et al., 2009).
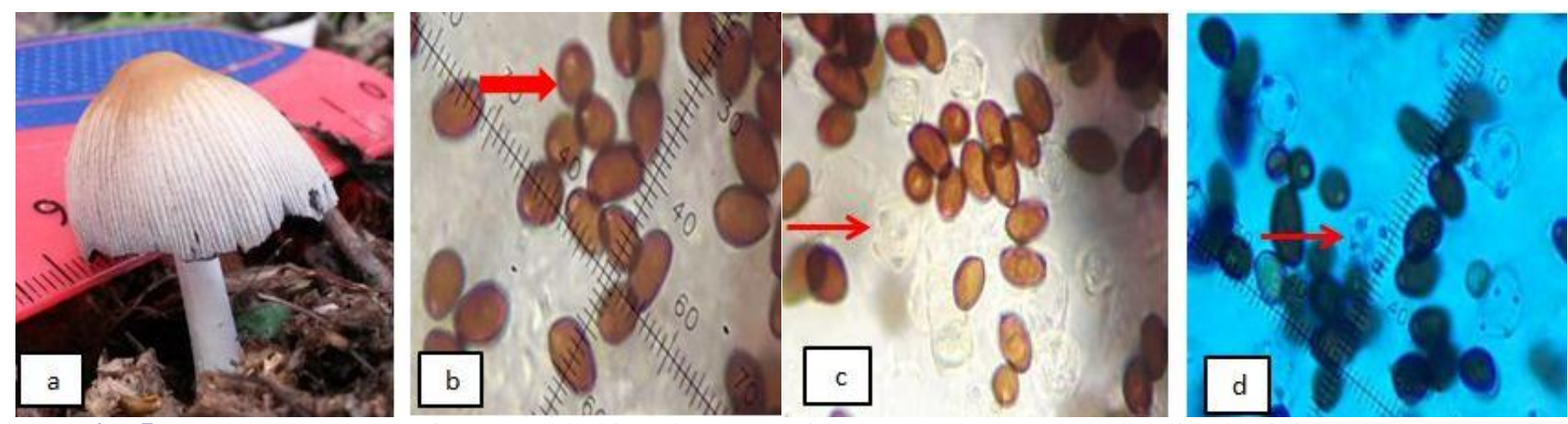

Fig. 5 : C.atramentaria. a, in natural habitat; b, spore with pore at the top, c; d, hyaline basidium. b-d (1000x). 
Species : Coprinopsis strossmayeri (Schulzer) Redhead, Vilgalys \& Moncalvo (=Coprinus strossmayeri Schulz) (Fig. 6)

Macroscopic features : Cap 15-20 mm broad, 15-22 $\mathrm{mm}$ height, white, brown or gray, oval, conical as age, covered by white to brown membranes scales in the early stages that continues to appear in the form of separate pieces on the surface centered at the top while become sparse or disappear at the irregular or wavy margin; Gills: free, white to gray and with age turns brown; Stipe: $23-55 \times 3-6 \mathrm{~mm}$, white to creamy, cylindrical, straight, with velar remnants scattered, central, hollow; ring and volva absent.

Microscopic features: Basidium $27.5 \times 5 \mu \mathrm{m}, 4-$ spored; spore 6.0-8.0 $\times$ 4.0-5.0 $\mu \mathrm{m}$, ovoid, truncate, pore in the rounded top, deep red to brown, smooth; pleurocystidia and cheilocystidia, similar utriform, may give the form of lagineform (a cystidia with a neck that is half the width of the cell body); clamp connections absent.

Gregarious under dead trees near the river, unknown edibility, Dukan / Suliamaniya district, April to May, Their edibility is unknown. C. strossmayeri was collected from Turkey (Sesli and Denchev, 2008) and from Morocco (El-Akil et al., 2014) and Armenia (Badalyan et al., 2011) and Italy (Saitta et al., 2011). C. strossmayeri is species that is rich in non-saturated fatty acid, such as palmitic acid, linoleic acid and stearic acid, which need to be further investigated for nutriceuticals or as dietary supplements (Mkrtchyan, 2014; Badalyan, 2016).
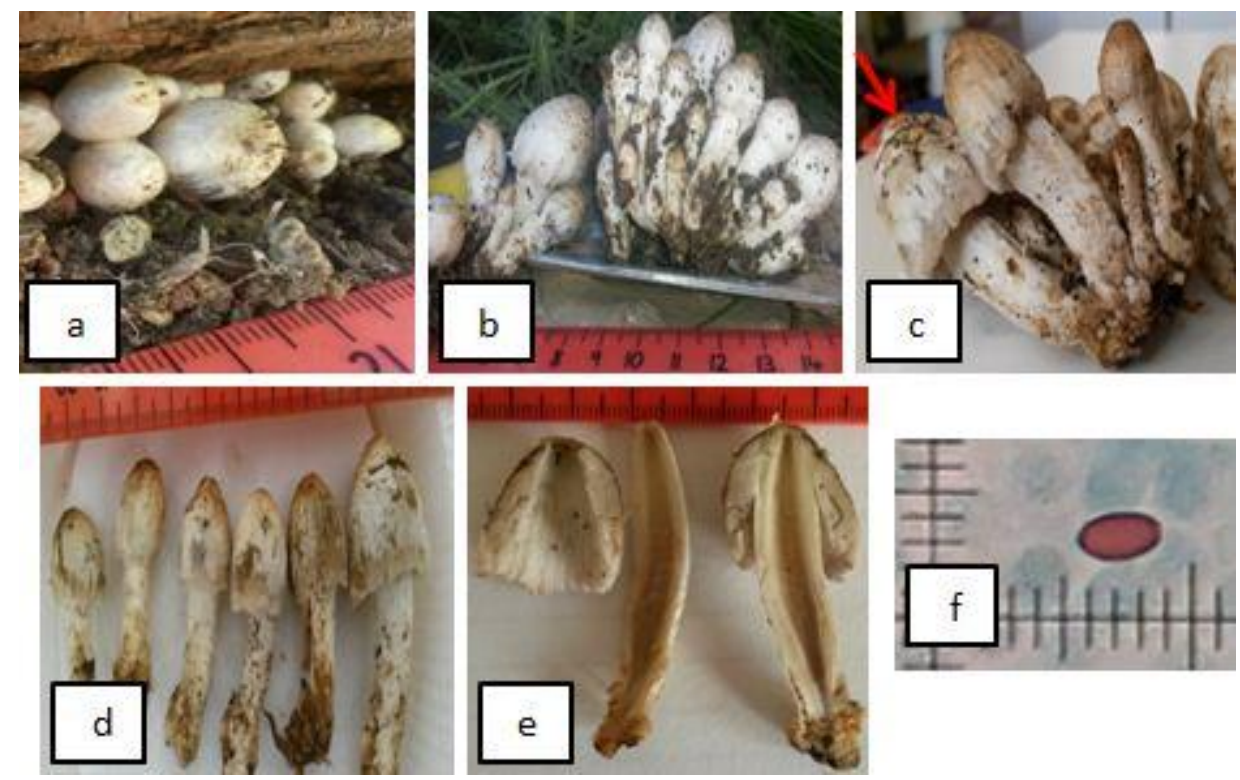

Fig. 6: C. strossmayeri. a; b, in natural habitat; c; d, different stages of growth of the fruiting body; e, longitudinal section of the hollow stipe; $\mathrm{f}$, spore (40x).

\section{Family : Hymenogastraceae}

Species : Hymenogaster sp. Vitad (Fig. 7)

Macroscopic features: The fungus is characterized by its fruiting body like the Tuber, $33-36 \mathrm{~mm}$ broad, 1.5-30 mm thick, subglobose, wrinkled or grooved, irregular; Fertile layer: its cavities or chambers are large, irregular, smooth, brittle, black, juicy.

Microscopic features: Basidium $15 \times 11 \mu \mathrm{m}, 4$ - spored; spore 5.0-9.54 ×5 $\mu \mathrm{m}$, elliptical, doublewall, pore in the top of the spore, smooth, yellowish brown; mycelium is characterized by a yellowish brown color, clamp connections present; Cystidia $16-23 \times 7 \mu \mathrm{m}$, clavate. Solitary in the soil under the trees of Juglans sp., unknown edibility, Amadia/ Amadia district, March to April. Various species of Hymenogaster were recorded in several countries, including Turkey, İsmail et al. (2016) listed different species of Hymenogaster. 

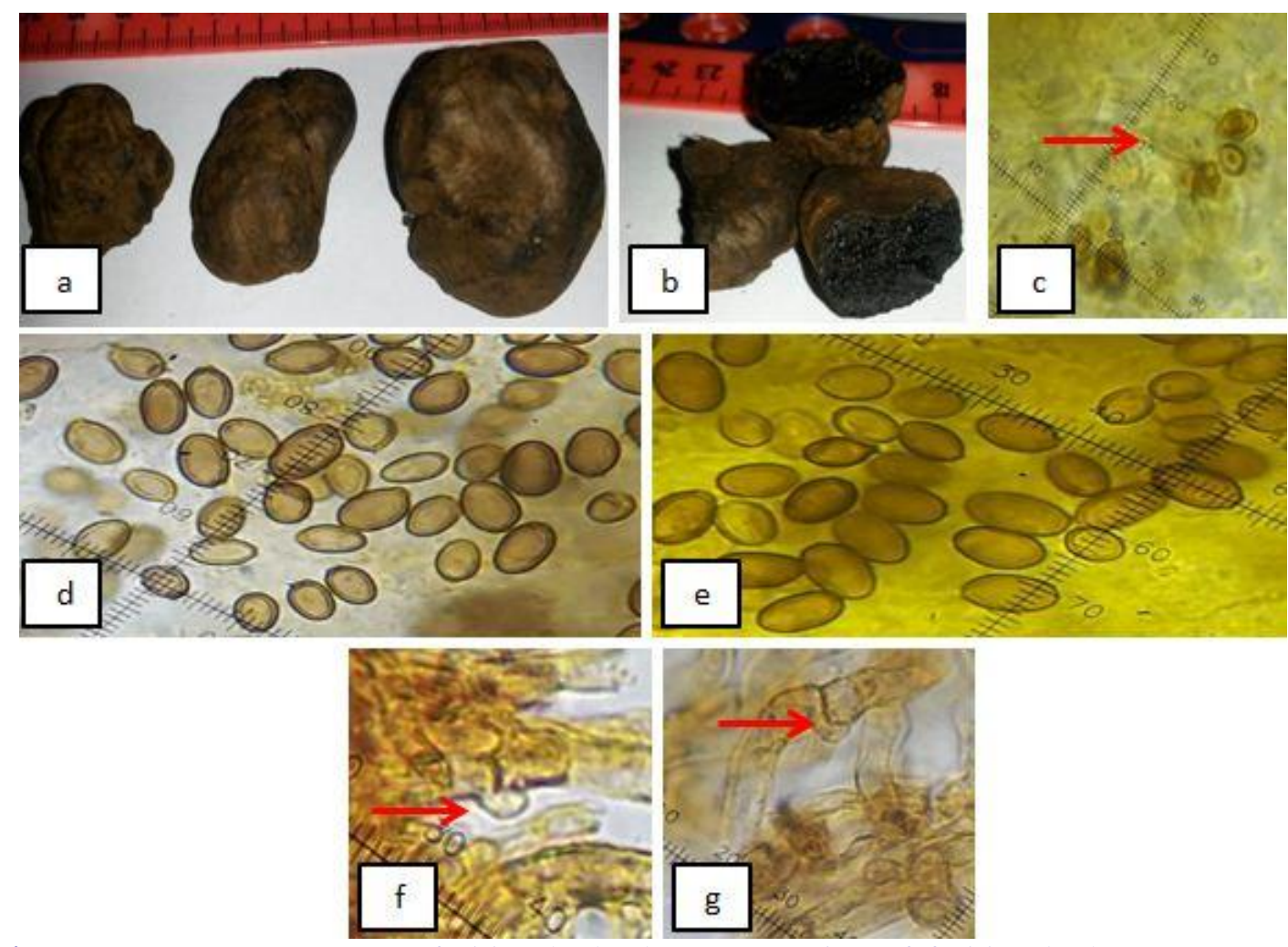

Fig. 7 : Hymenogaster sp. a, fruiting body; b, cross section of fruiting body; c, 4 -spored basidium ; d; e, spores; f; g; clamp connections. c - g, (1000x).

\section{Family : Inocybaceae}

Species : Inocybe glabripes J.E. Lange (=Inocybe microspora Ricken) (Fig. 8).

Macroscopic features: Cap $20-25 \mathrm{~mm}$ broad, light brown, flat with light lacunate, hairy with radial fibrillose; Gills: attached to stipe, light brown, unequal; stipe: 40-45 × 3-5 mm, light brown to creamy, cylindrical, bent, smooth, central, hollow; ring and volva absent.

Microscopic features : Basidium $22.5 \times 12.5 \mu \mathrm{m}$, 4-spored; spore 7.5-8 × 3.75-5.0 $\mu \mathrm{m}$, light brown, almond, smooth; pleurocystidia 17.5-20.0 × 7.5$8.75 \mu \mathrm{m}$, clavate or utriform $60.0-65.0 \times 12.5-17.5$ $\mu \mathrm{m}$, hyaline, muricate (yellowish brown crystalline), as well as the existence of a similar cheilocystidia similar to the shape and size of the pleurocystidia.

Gregarious in the soil among leaf litter in mixed forest, unknown edibility, Chuwarta / Suliamaniya district, March to April. This species was found in
Europe (Kuyper, 1986), New Zealand (McKenzie et al., 2006), Australia (Tedersoo et al., 2008), Argentina (Becerra et al., 2009), Pakistan (Sultana et al., 2011; Saba et al., 2015) and Turkey (Acar et al., 2015).

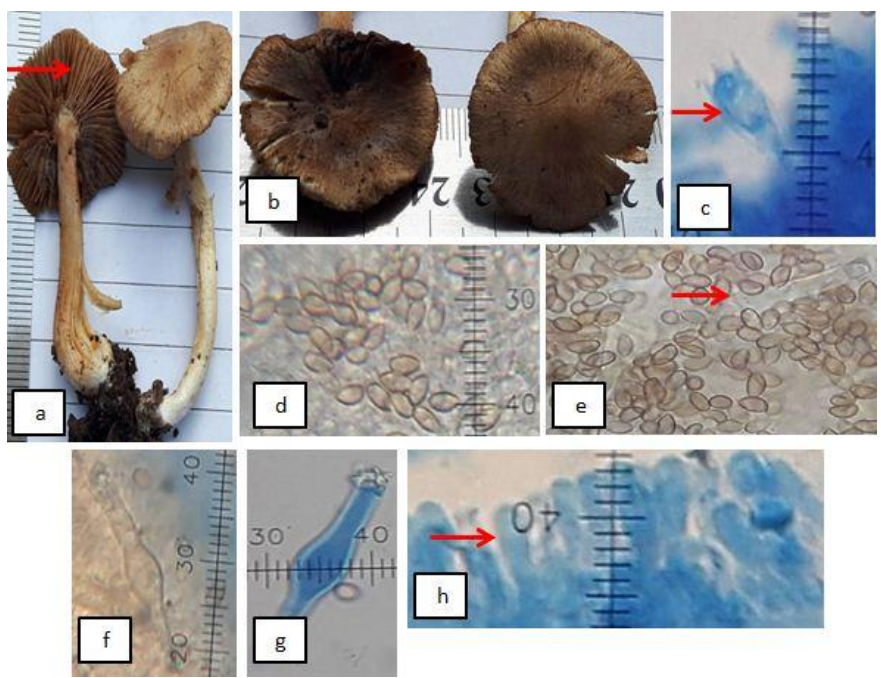

Fig. 8: I. glabripes. a,fruiting body, b, cap with hairy scales, c, basidium; d, spores; e; f, hyaline utriform cystidia ; g, pigmented cystidia; h, clavate cystidia. c-h, (400×). 
Species : Inocybe hystrix (Fr.) P.Karst (Fig. 9)

Macroscopic features: Cap 30 - $35 \mathrm{~mm}$ broad, dark brown at the top becomes lighter towards the wavy margin , convex broad, with wide umbonate, its surface covered with hairs that appear in a tuft spread evenly from the top of the cap to its margin; Gills: attached to the stipe, light brown then turn to dark brown, crowded, unequal in length; Stipe $30 \times$ $5 \mathrm{~mm}$, creamy, cylindrical, equal, surrounded by brown hairs centered at its base, central, hollow, without a ring and volva.

Microscopic features: Basidia 20-21 × 7.5-9.0 $\mu \mathrm{m}$, 4-spored; Spore 6-13 × 5.5-6.0 $\mu \mathrm{m}$, cylindrical to oblong, brown color, pore in the top; Pleurocystidia $52.5 \times 12 \mu \mathrm{m}$, hyaline, swollen, capitates; clamp connections present.

The fugus, Inocybe hystrix is found solitary, under the trunks of decaying populous trees and from forest leaves and decaying leaves, unknown edibility, Hujran forest / Erbil district March to April. This fungus was found in Korea (Seok et al., 2000), Bulgaria (Denchev and Assyov, 2010) and in North America (Kuo, 2005). There are no studies on the species of medical or nutritional importance.

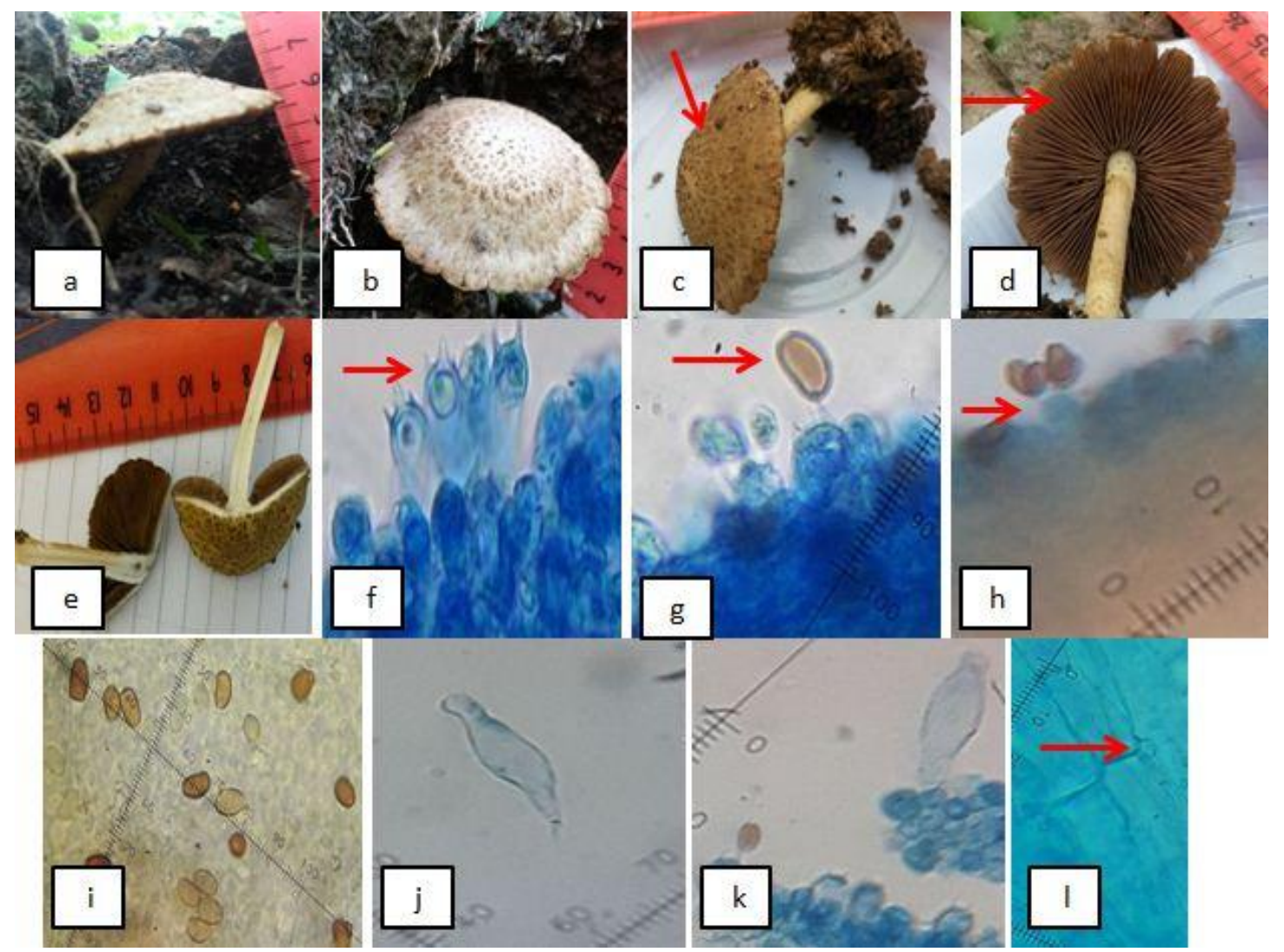

Fig. 9: I. hystrix. a; b, fruiting body in natural habit; c, cap with hairy scales; d, gills; e, longitudinal section of fruiting body; f; g, basidium (1000x); h, basidium (400x); I, spores (400x); j; k, utriform cystidia (400x); l, clamp connection (1000x) .

\section{Family : Tricholomataceae}

Species : Tricholoma scalpturatum (Fr.) Qu él. [=Tricholoma argyraceum (Bull.) Gillet] (Fig. 10).

Macroscopic features: Cap 18-40 mm broad, white to cream or brownish brown to gray and darker in color, convex to flat; Gills: crowded, white before the harvest turns into a light beige after the harvest, attached to the stipe; Stipe $20-50 \times 3-8 \mathrm{~mm}$, white, cylindrical, bulbous in some specimens and spiked in other samples, fibrous, central, non hollow with membranous ring; volva absent. 
Microscopic features: Basidia 30-35 × $7.0 \mu \mathrm{m}$; 4spored; spore $7.5 \times 5.0 \mu \mathrm{m}$, double wall, oval, hyaline, smooth; cheilocystidia 30.0-42.5 × 7.5$10.0 \mu \mathrm{m}$, narrowly clavate; clamp connections absent.

Gregarious in the soil among leaf litter in mixed forest, unknown edibility, Chuwarta / Suliamaniya district, March to April. This fungus was found in Italy (Zotti and et al., 2008), Turkey (Kaya, 2009), Iran (Jadidiyan and Asef, 2014), Estonia (Kalamees, 2010) and Russia (Perevedentseva, 2011). The fungi have ectomyccorhiza with the root of many trees and shrubs (Carriconde et al., 2008), which play an important role in promoting plant growth (Cripps, 2001).

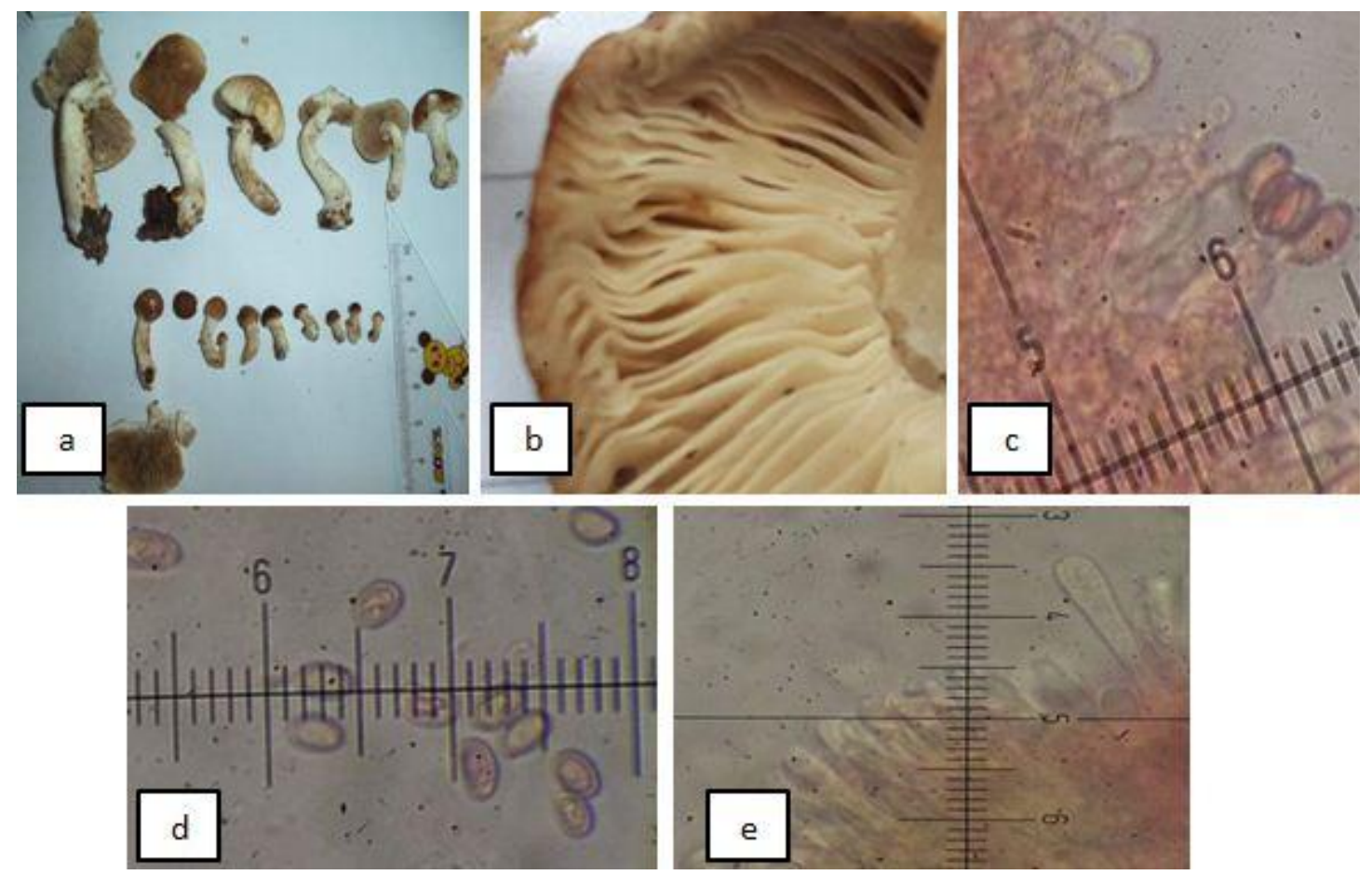

Fig. 10: T. scalpturatum. a , different growth stages of the fruiting body; b, gills; 4-spored basidia in surface view and in section; d, spores; e, cystidia. c - e (400×).

\section{Order : Boletales}

Family : Boletaceae

Species: Boletus luridus (Schaeff.) Murrill. [=Suillellus luridus (Schaeff.) Murrill] (Figs. 11 and 12)

Macroscopic features: Cap 40-130 mm broad, brown to olivaceous, smooth, hemispherical in the early stages and with age becomes convex or flat convex and becomes sticky texture; the underside of the cap (the fertile layer or maroon layer) is tubular and ends with olivaceous circular pores. The characteristics of the fertile layer are the ease of separating it from the rest of the cap, maroon layer, the presence of this layer is the main characteristic feature of this species, reddish brown or brown by age, cap flesh white; stipe $60-80 \times 20$ $30 \mathrm{~mm}$, brown to olivaceous, club, cylindrical or swollen base, acuminate to the apex, reticulate with vertically elongated trim, rooting, thick, center, solid, stipe flesh dark brown; ring and volva absent.

Microscopic features: Basidia 22.5-27.5 × 10.0$12.5 \mu \mathrm{m}, 4$-spored; spore 10-13 $\times$ 4-6 $\mu \mathrm{m}$, olivaceous to brown, fusiform to elliptical, smooth; Pleurostidia and cheilocystidia, fusiform; clamp connections absent.

Solitary in the soil among leaf litter in forest trees of Juglans sp. and Quercus spp., unknown edibility, April to May, Zewiya-Pera Magrun Mountain / Suliamaniya district. This fungus was 
recorded in Turkey (Pekşen and Karaca, 2003; Sesli and Denchev, 2008) and India (Kumar and Sharma, 2011). Wang and $\mathrm{Xu}$ (2014) pointed to the efficacy of the biological extracts of B. luridus as an antioxidant that was attributed to its total phenol content. Wang et al. (2017) referred to the accumulation of heavy metals in the fungal body of the fungus, indicating its role as agents for the removal of heavy metals from the environment.
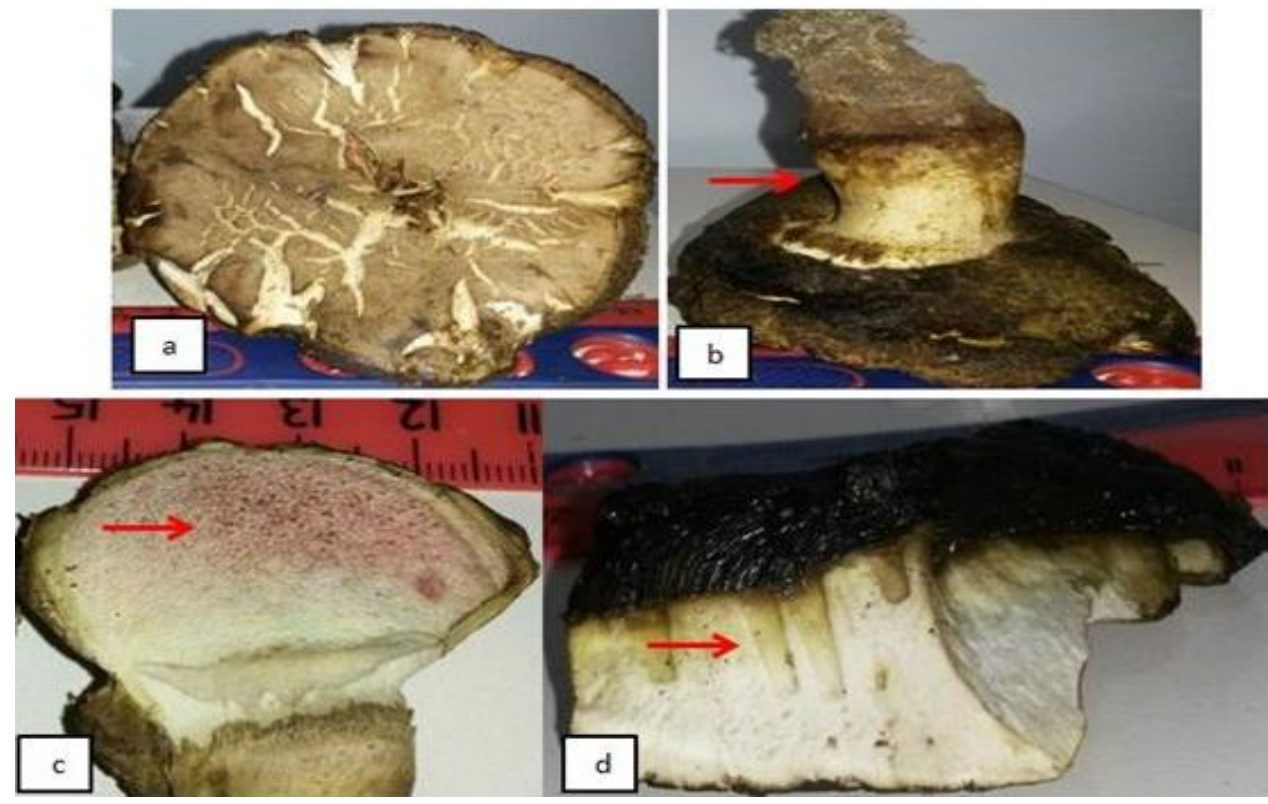

Fig. 11: B. luridus. a, general morphology in the lab; b, club stipe; c, maroon layer; d, white grooves in the cross section of the cap.
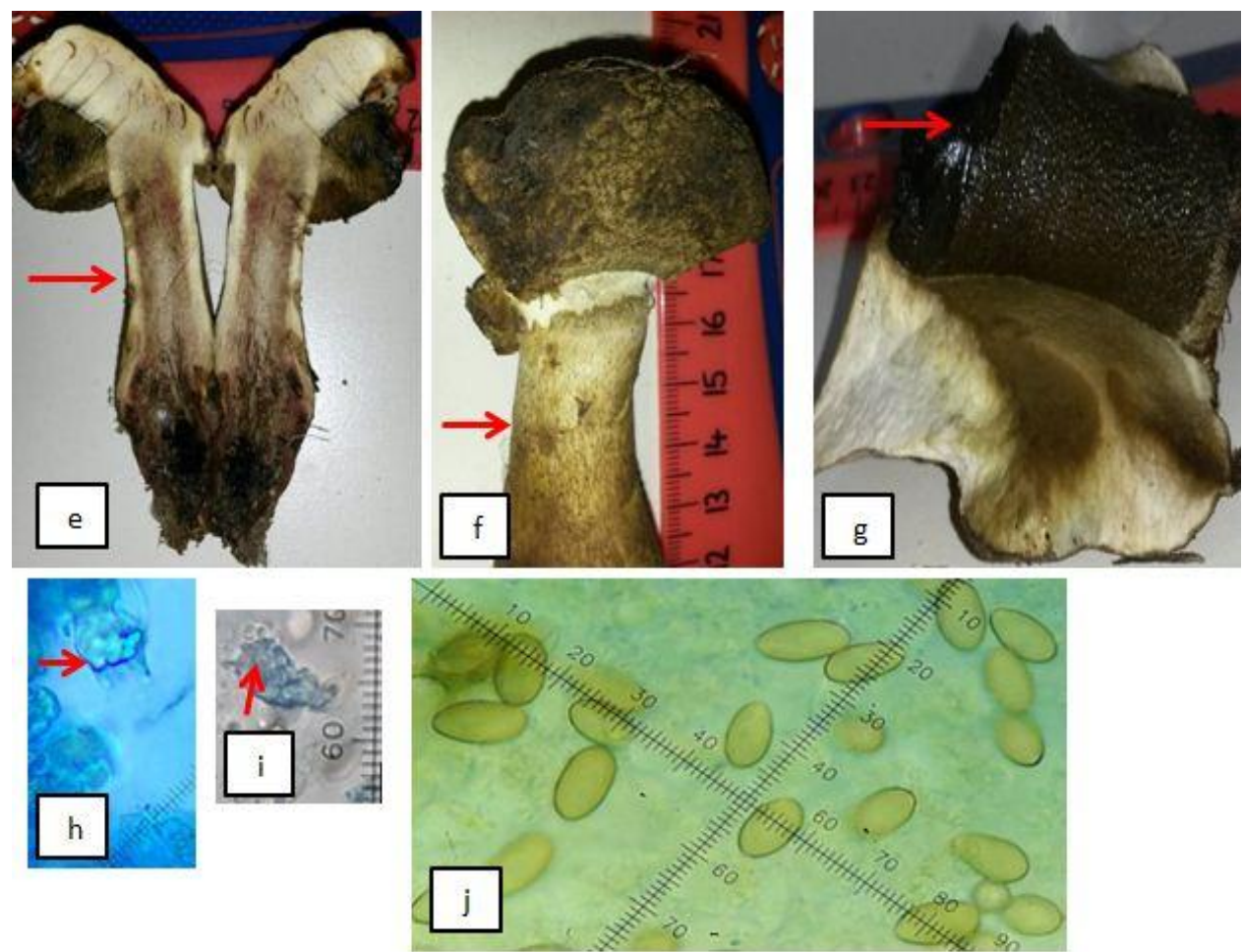

Fig. 12: B. luridus. e, stipe flesh; f, reticulate with vertically elongated trim; g, fertile layer; h, basidium (1000x); I, basidium (400x); spores (1000×). 


\section{Order : Polyporales}

Family: Ganodermateaceae

Species: Ganoderma adspersum (Schulzer) Donk

(Figs. 13 and 14).

Macroscopic features: Fruiting body: sesslile, large size $250 \mathrm{~mm}$ broad, $95 \mathrm{~mm}$ thick, rough textures (wooden), deep gray - brown, the surface of the body is covered with a semi-leather layer, hard, knobbly, the edges of the cap are obtuse, thick, rounded, white in the growing season or in the active growth stage; Flesh: dark brown, wooden textures, thick; Fertile layer: $35 \mathrm{~mm}$ thick, tubular thicker than flesh, the tubes are not separated from each other, dark brown color ends with pores representing the bottom surface of the fruiting body; Pores: rounded, yellowish brown, white in active growth stage.

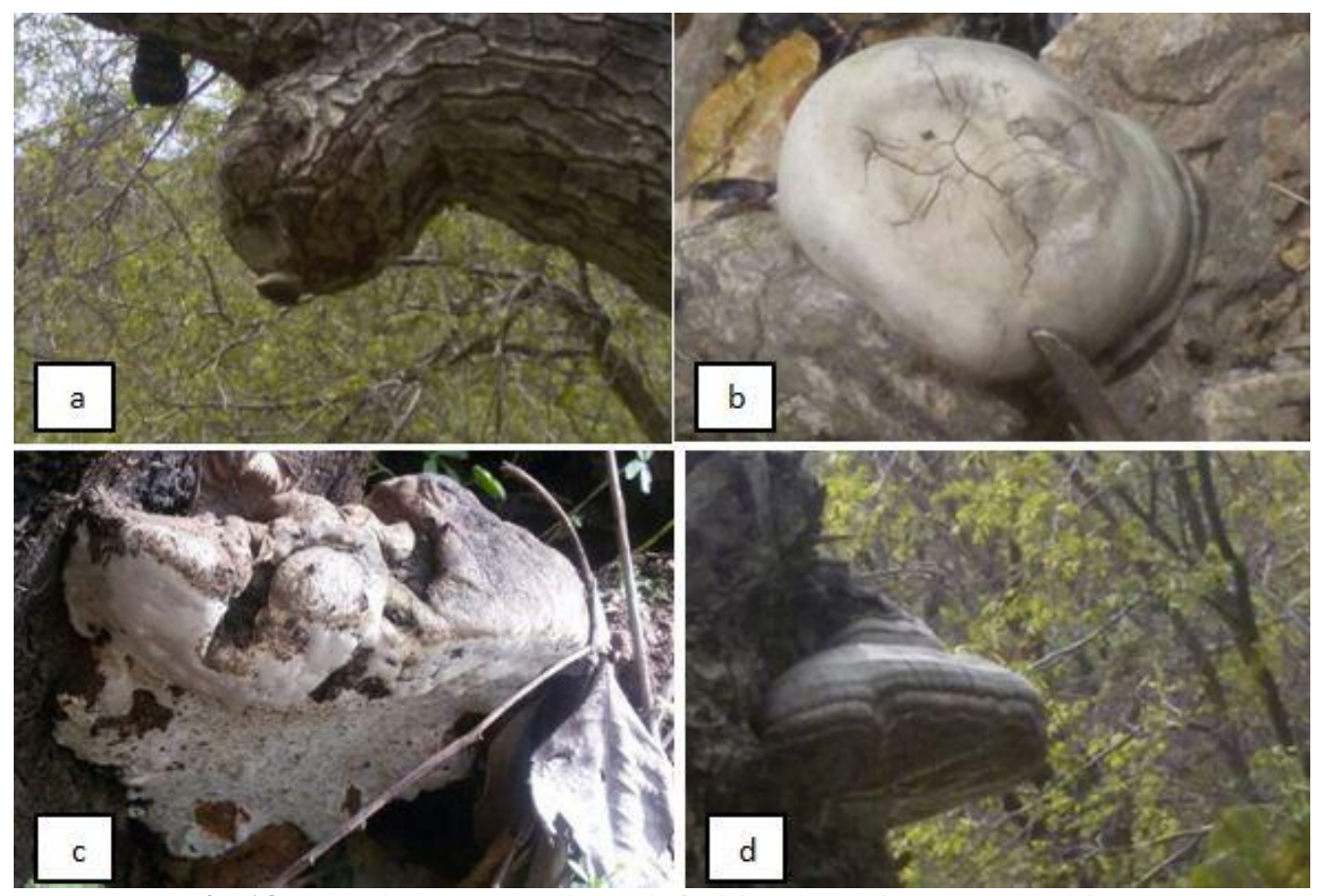

Fig 13: G. adspersum. a, b, c, d, fruiting body in natural habitat.

Microscopic features: Basidia 22-30 × 6-12 $\mu \mathrm{m}$; Spore: $8.75 \times 5.0 \mu \mathrm{m}$, oval, truncate, double wall, brownish reddish, smooth; the hypha is made up of three types, The first type is the generative hypha, which is characterized by clamp connections and the skeletal hypha that have their branches, cellular contents, few septa and lack of clamp connections, and the binding hypha. It has a lot of branching and also a few cellular contents.

Solitary, collected from Juglans sp. tree trunks, on the lower and upper part of the tree trunk which is perennial parts on these trees, unknown edibility, March to April, twilla / Suliamaniya district. O'Reilly (2011) reported that the fungus on the lower part of the logs, unlike the current study, found that the fungus parasites on the trunk trees near the base and in locations away from them (sometimes near the top of the trunk). The species has a wide spread in Britain and Ireland, as found in most of continental Europe and is the most common in central and northern Europe. Ganoderma is widely used in traditional medicine in countries such as Korea, China and Japan hundreds of years ago (Lee et al., 2009). The study by Tel-Çayan et al. (2015), which included the isolation of several phenolic compounds and amino acids of the species, as well as proving the effectiveness of the species such as anti-oxidants, anti-cancer, antiviruses, anti-cholinesterase and many other biological activities, Which included the isolation of several phenolic compounds and amino acids of 
the species, as well as proving the effectiveness of the species as an antioxidant and cholinesterase is the first study of its kind of G. adspersum. Kivrak (2015) pointed to the richness of the body of vitamins $\mathrm{B}$ and $\mathrm{C}$, which gave it importance in many therapeutic, nutritional and cosmetic applications and industrial supplements. The researcher pointed to the richness of the body of the yeast in the two vitamins and carbohydrates, amino acids and monoclonal sugars in which the trehalose and mannitol of sugars Monoclonal dominant in the body of the sex of the species.

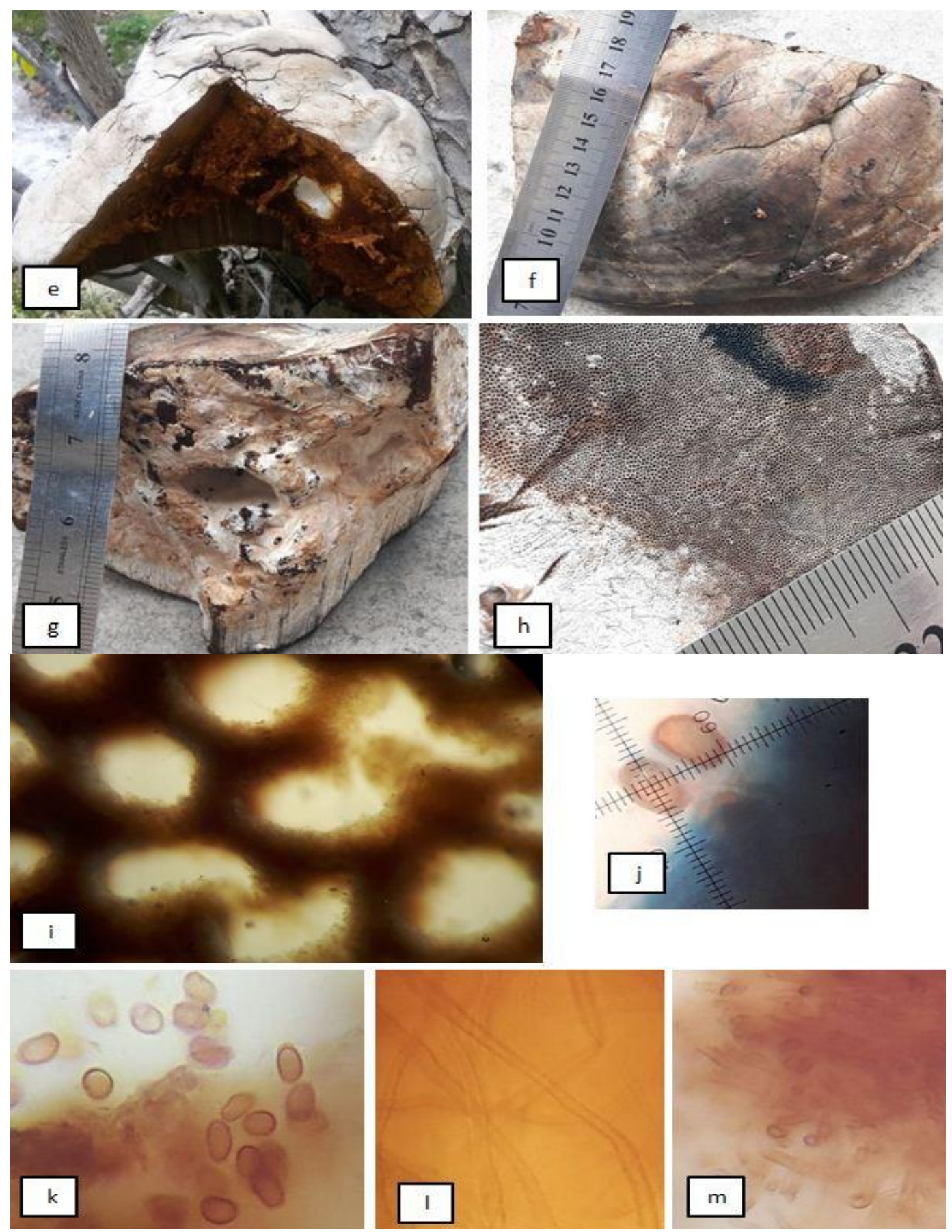

Fig. 14: G. adspersum. e, fruiting body in natural habitat; f, surface of fruiting body; g, cross section of fruiting body; h, bottom surface with pores of fruiting body; I, pores $(100 \times)$; , basidium (1000x); k, spores; 1, skeletal hypha; m, binding hypha. k-m (400×). 


\section{Family: Polyporaceae}

Species: Polyporus arcularius (Batsch) Fries (Fig. 15)

Macroscopic features: Fruiting body is tiny; Cap $19 \mathrm{~mm}$ broad, light brown, round, flat, with a slight depress at the center of the cap, covered with soft brown scales, the margin is surrounded by soft brown hairs, the top of the hair is pointed and its color is dark brown; Fertile layer: perforated, brown, radially arranged; Stipe 20-25 × 4-5 mm, yellowish brown, cylindrical, equal, covered with hairs, non-centralized, solid; ring and volva absent.
Microscopic features: Basidia $25.5 \times 4.0-5.0 \mu \mathrm{m}$, 4-spored; Spore 7-10 × 2-3 $\mu \mathrm{m}$, cylindrical, hyaline, smooth; clamp connections absent.

Solitary, collected from bark trees live mountain oak near the base, unknown edibility, Hujran forest / Erbil district, March to April. The species registry is from New Zealand (Buchanan and Rwarden, 2000), Costa Rica (Velázquez and Ruiz-Boyer, 2005), Brazil (Groposo and Loguercio-Leite, 2005) and Argentina (Robledo and Rajchenberg, 2007). No studies on this species are available in terms of their chemical content, nutritional value or therapeutic value.
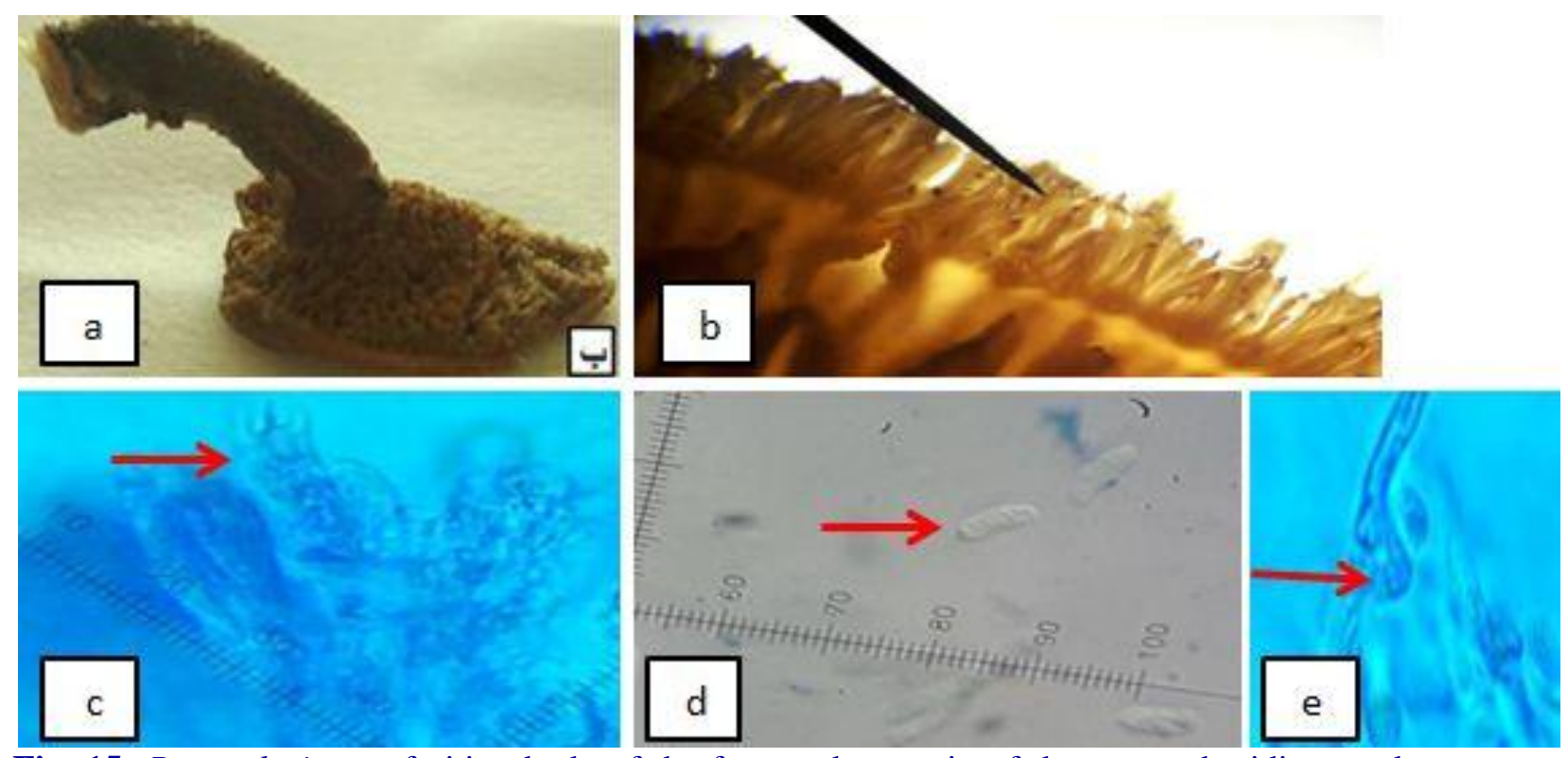

Fig. 15: P. arcularius. a, fruiting body of the fungus; b, margin of the cap; c, basidium ; d, spore ; e, clamp connection. c-e $(400 \times)$.

\section{Order: Russulales}

Family: Russulaceae

Species: Russula delica Fr. (Fig. 16).

Macroscopic features: Cap 100-120 mm broad, white mixed with brown, depressed from the center, funnel shaped, margin folded towards inside, smooth, dry; Gills: yellowish brown, attached to the stipe, decurrent, parallel, spaced, unequal in length, thin, narrow; stipe 44-69 × 28-53 mm, white, cylindrical, truncated, thick, strong, smooth; ring and volva absent; Flesh: white and color unchanged after cutting. In general the textures are inflexible and breakable.
Microscopic features: Basidia 4-spored; spore 8$11 \times 8.5-6.5 \mu \mathrm{m}$, hyaline, oval, rounded, obtuse wartse, globose cells called shaerocysts, are located in the trama region arranged in the form of nests that are surrounded by elongated filaments. It is called heteromerous trama and thus different from the rest of the mushrooms; Cystidia: rostrate; clamp connections present.

Gregarious, collected from mountainous areas, the fungus grows on the surface of the soil and some are found half buried in the soil, unknown edibility, Kalar / Suliamaniya, April to May. This fungus was found in Turkey (Sesli and Denchey, 
2008) and India (Kumar et al., 2014). The general label for mushrooms is milk-white brittle gill. Short-stipe Russula is often confused with
Lactarius vellereus or other white fungus, but Russula delica is free of milky secretions (Hard, 1961).
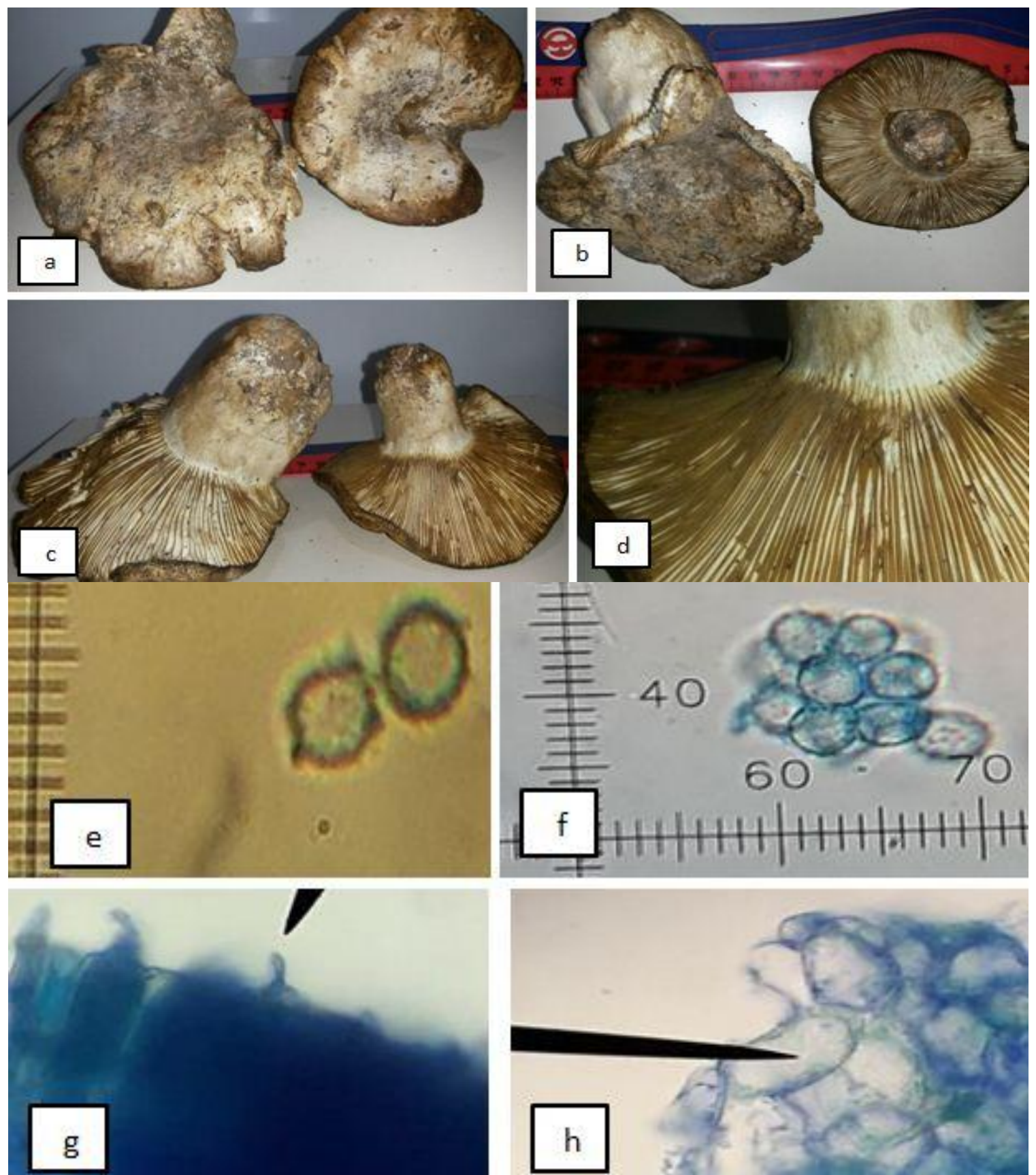

Fig. 16: $R$. dellica. a, b, c, general morphology in the lab; d, gills; e, hyaline spores; $\mathrm{f}$, pigmented spores; g, cystidia; h, shaerocysts. e-h (400x).

\section{Conflict of interest statement}

Authors declare that they have no conflict of interest.

\section{References}

Acar, İ., Uzun, Y., Demirel, K., Keleaş, A., 2015. Macrofungal diversity of Hani (Diyarbakır/ 
Turkey) district. Biological Diversity and Conservation, 8, 28-34.

AL- Qaissi, A.R., 2014. A study on the activity of some mushrooms in bioremediation of petroleum wastewater in refineries companyBaji. Ph.D thesis, Tikrit University, Iraq

Albrechtova, J., Latr, A., Nedorost, L., Pokluda, R., Posta, K., Vosatka, M., 2012. Dual inoculation with mycorrhizal and saprotrophic fungi applicable in sustainable cultivation improves the yield and nutritive value of onion. Sci. World J. 2012, 374091. 8p.

AL-Khesraji, T.O., 2016. Seven new records of ascomycetous macrofungi from Suliamaniya province (Northeast of Iraq). J. Biol. Agric. Health. 6, 94-107.

AL-Khesraji, T.O., 2018. Two Peziza taxa (Peziza proteana f. proteana (Boud.) Seaver and Peziza proteana $\mathrm{f}$. sparassoides (Boud.) Korf) new to Iraq and bordering countries. Afr. J. Plant Sci. 12, 24-27.

Amandeep, K., Atri, N., Munruchi, K., 2015. A Checklist of Coprophilous Agarics of India. CREAM. 5, 322-348.

Arora, D., 1986. Mushrooms demystified. A comprehensive guide to the fleshy fungi. Berkeley. Ten Speed Press, California.

Badalyan, S.M., 2016. Fatty acid composition of different collections of coprinoid mushrooms (Agaricomycetes) and their nutritional and medicinal values. Int. J. Med. Mushroom. 18(10), 883-893.

Badalyan, S.M., Szafranki, K., Hoegger, P.J., Navarro-gozález, M., Majcherczyk, A., Kues, U., 2011. New Armenian wood-associated coprinoid mushrooms: Coprinopsis strossmayeri and Coprinellus aff. radians. Diversity. 3, 136-154.

Becerra, A.G., Nouhra, E.R., Silva, M.P., Mckay, D., 2009. Ectomycorrhizae, arbuscular mycorrhizae, and dark-septate fungi on Salix humboldtiana in two riparian populations from central Argentina. Mycoscience. 50, 343-352.

Buchanan, PK., Rwarden, L., 2000. An annotated checklist of polypore and polypore-like fungi recorded from New Zealand. New Zeal. J. Bot. $38,265-323$.
Cai, I. Q., Tullos, R.E., Tang, L.P., Tolgor, B., Zhang, P., Chen, Z.H., Yang, Z.L., 2014. Multilocus phylogeny of lethal amanitas: Implications for species diversity and historical biogeography. BMC Evol. Biol. 14(1), 143.

Carriconde, F., Gardes, M., Jargeat, P., Heilmannclausen, J., Mouhamadou, B., Gryta, H., 2008. Population evidence of cryptic species and geographical structure in the cosmopolitan ectomycorrhizal fungus, Tricholoma scalpturatum. Microb. Ecol. 56(3), 513-524.

Chang, S., Miles, G.P., 2004. Mushrooms: Cultivation, nutritional value, medicinal effects and environmental impact. CRC Press. 436p.

Chen, Z., Zhang, P., Zhang, Z., 2014. Investigation and analysis of 102 mushroom poisoning cases in Southern China from 1994 to 2012. Fungal Divers. 64(1), 123-131.

Christensen, M., Noordeloos, M.E., 1999. Notulae ad Floram agaricinam neerlandicam-XXXVI. Tricholoma. Persoonia-Mol. Phyl. Evol. Fungi. 17(2), 295-317.

Cocchi, L., Vescovi, L., Petrini, L.E., Petrini, O., 2006. Heavy metals in edible mushrooms in Italy. Food Chem. 98 (2), 277-284.

Coimbra, V., 2015. Checklist of Central and South American Agaricales (Basidiomycota) II: Strophariaceae. Mycosphere. 6, 441-458.

Corner, E., 1984. Ad Polyporaceas II. Polyporus, Mycobonia, and Echinochaete. Beih. Nova Hedw. 78, 1-129.

Cripps, C.L., 2001. Mycorrhizal fungi of aspen forests: natural occurrence and potential applications. Sustaining Aspen in Western Landscapes: Symposium Proceedings. Proceedings RMRS-P-18. U.S. Department of Agriculture, Forest Service, Rocky Mountain Research Station. Fort Collins, CO. pp.285-298.

Cowan, A., 2001. Fungi - Life Support for Ecosystems. Essential ARB. 4, 1-5.

Dai, Y.C., Cui, B.K., 2011. Fomitiporia ellipsoidea has the largest fruiting body among the fungi. Fungal Biol. 115(9), 813-814.

Dai, Y.C., Yang, Z.L., Cui, B.K., Yu, C.J., Zhou, L.W., 2009. Species diversity and utilization of medicinal mushrooms and fungi in China. Int. J. Med. Mushroom. 11(3), 287-302. 
Denchev, C.M., Assyov, B., 2010. Checklist of the larger basidiomycetes in Bulgaria. Mycotaxon. 111(1), 279-282.

Dodge, C.W., Zeller, S.M., 1934. Hymenogaster and related genera. Ann. Mo. Bot. Gard. 21(4), 625-708.

El-Akil, M., Touhami, A.O., Benkirane, R., Doura, A., 2014. Étude de quelques champignons coprinoïdes de la forêt domaniale du site minier Jerada (Nord-Est du Maroc) dont Coprinellus bipellis et Coprinopsis strossmayeri sont nouvelles pour la flore fongique du Maroc. J. Appl. Biosci. 82(1), 7389-7402.

Farook, M., Abida Akram, R.U., Khsana Afzal, K., Nazir, S., 2013. Ethno-morphological studies of mushrooms collected from Soon Valley. IOSR J. Phparm. Biol. Sci. 8(5), 5-11.

Groposo, C., Loguercio-Leite, C., 2005. Contribution to the lignocellulolytic fungi (Basidiomycetes) of the Atlantic Rain Forest in Southern Brazil. Mycotaxon. 92, 103-106.

Halling, R.E., Mueller, G.M., 2005. Common mushrooms of the Talamanca Mountains, Costa Rica, New York Botanical Garden.

Hard, M.E., 1961. The mushroom: edible and otherwise: its habitat and its time of growth. A guide to the study of mushrooms, with special reference to the edible and poisonous varieties, with a view of opening up to the student of nature a wide field of useful and interesting knowledge, Hafner Pub. Co.

Heleno, S.A., Ferreira, I.C., Calhelha, R.C., Esteves, A.P., Martins, A., Queiroz, M.J.R., 2014. Cytotoxicity of Coprinopsis atramentaria extract, organic acids and their synthesized methylated and glucuronate derivatives. Food Res. Int. 55, 170-175.

Hongo, T., 1953. Larger fungi of the provinces of Omi and Yamashiro 4. J. Japan. Bot. 28, 69-75.

İsmail, Ş.E.N., 2016 .Checklist of Turkish Truffles. Turk. J. Life Sci. 1(2), 103-109.

Jadidiyan, A., Asef, M. R., New records of agaric fungi from Hamedan province, Iran (Familines Bolbitiaceae, Inocybaceae, Psathyrellaceae and Tricholomataceae). Rostaniha. 16(1), 101-108.

Kalamees, K., 2010. Checklist of the species of the genus Tricholoma(Agaricales, Agaricomycetes) in Estonia. Fol. Cryot. Eston. 47, 27-36.

Karim, M., Kavosi, M.R., Hajizadeh, G., 2013. Macrofungal communities in Hyrcanian forests, North of Iran: Relationships with season and forest types. Ecol. Balkan. 5(1), 87-96.

Kaya, A., 2009. Macrofungal diversity of Adiyaman province (Turkey). Mycotaxon. 110, 43-46.

Kirk, P., Cannon, P., David, J., Stalpers, J., 2001. Dictionary of the Fungi (9th) CAB International, Oxon.

Kirk, P., Cannon, P., Minter, D., Stalpers, J., 2008. Dictionary of the Fungi $\left(10^{\text {th }}\right.$ Edn). Wallingford, UK.

Knudsen, H., Vesteroholt, J., 2008. Funga Nordica Nordsvamp. Copenhagen, Denmark.

Korn, E.D., 1982. Actin polymerization and its regulation by proteins from non muscle cells. Physiol. Rev. 62(2), 672-737.

Kumar, R., Ttapwal, A., Pandey, S., Raja-rishi, R., Mishra, G., Giri, K., 2014. Six unrecorded species of Russula (Russulales) from Nagaland, India and their nutrient composition. Nusan. Biosci. 6(1), 3-38.

Kumar, S., Sharma, Y.P., 2011. Diversity of wild mushrooms from Jammu and Kashmir (India). In: Proceedings of the 7th International Conference on Mushroom Biology and Mushroom Products (ICMBMP7). Section: Economical and societal features. pp. 568-577.

Kuo, M., 2005, February. Inocybe hystrix. Retrieved from the MushroomExpert.Com Web site: http://www.mushroomexpert.com/inocybe _hystrix.html

Kuo, M. ,2006, September. Agrocybe praecox. Retrieved from the MushroomExpert.Com Web site: http://www.mushroomexpert.com/ agrocybe_praecox.html

Kuo, M., 2008, February. Coprinopsis atramentaria. Retrieved from the Mushroom Expert.Com Web site: http://www.mushroom expert.com/ coprinopsis_atramentaria.html

Kuo, M., 2015, January. Boletus luridus. Retrieved from the MushroomExpert.Com Web site: http://www.mushroomexpert.com/boletus_lurid us.html

Kuyper, T.W., 1986. A revision of the genus 
Inocybe in Europe. I. Subgenus Inosperma and the smooth-spored species of subgenus Inocybe Persoonia-Suppl. 3(1), 1-247.

Lahony, S.R.A., Mohammad, M.K., Ali, H.H., AlMoussawi, A. A., Al-Rasul, M.S.A., 2013. Hawraman lowest zone, Kurdistan province north east of Iraq. Bull. Iraq Nat. Hist. Mus. 12, 7-34.

Lee, I., Seo, J., Kim, J., Kim, H., Youn, U., Lee, J., Jung, H., Na, M., Hattori, M., Min, B. and Bae, K., 2009. Lanostane triterpenes from the fruiting bodies of Ganoderma lucidum and their inhibitory effects on adipocyte differentiation in 3T3-L1 cells. J. Nat. Prod. 73(2), 172-176.

Lo, K.M., Cheung, P.C., 2005. Antioxidant activity of extracts from the fruiting bodies of Agrocybe aegerita var. alba. Food Chem. 89(4), 533-539.

Mati, E., 2009. Natural dyeing plants in Kurdistan, Iraq. M.Sc., dissertation, Uppsala University.

McKenzie, E.H.C., Johnston, P.R., Buchanan, P.K., 2006. Checklist of fungi on teatree (Kunzea and Leptospermum species) in New Zealand. New Zeal. J. Bot. 44(3), 293-335.

Mkrtchyan, J., 2014. Qualitative analysis of fatty acids composition in different collections of coprinoid mushrooms. Proc. Yerevan State Univ. Chem. Biol. 1, 37-41.

Molina, R., O’Dell, T., Luoma, D., Amaranthus, M., Castellano, M., Russell, K., 1993. Biology, ecology and social as-pects of wild edible mushrooms in the forests of thePacific Northwest: A preface to managing commercial harvest. General Technical Report PNW-GTR309, USDA ForestService, Pacific Northwest Research Station, Portland. 42p.

Mueller, G.M., Schmit, J.P., Leacock, P.R., Buyck, B., Cifuentes , J., Desjardin, D.E., Halling, R.E., Hjortstam, K., Iturriaga, T., Larsson, K.H., Lodge, D.J., May, T.W., Minter, D., Rajchenberg, M., Redhead, S.A., Ryvarden , L., Trappe, J.M., Watling, R., Wu, Q., 2007. Global diversity and distribution of macrofungi. Biodivers. Conserv. 16, 37-48.

Muslat, M.M., Owaid, M.N., 2015. Polyporus spp. (Polyporaceae, Basidiomycota): Rare record from ecosystem of Fallujah, Iraq. Int. J. Environ. 4(3), 185-189.
Niveiro, N., Albertó, E., 2013. Checklist of the Argentine Agaricales 5. Agaricaceae. Mycotaxon. 122(1), 491-491.

O'Reilly, P., 2011. Fascinated by Fungi: Exploring the History, Mystery, Facts, and Fiction of the Underworld Kingdom of Mushrooms. First Nature.

Ostry, M.E., O'Brien, J.G., Anderson, N.A., 2011. Field guide to common macrofungi in eastern forests and their ecosystem functions, Government Printing Office.

Öztürk, M., Duru, M.E., Kivrak, Ş., Mercan-Doğan, N., Türkoglu, A., Özler, M.A., 2011. In vitro antioxidant, anticholinesterase and antimicrobial activity studies on three Agaricus species with fatty acid compositions and iron contents: A comparative study on the three most edible mushrooms. Food Chem. Toxicol. 49(6), 1353-1360.

Pacioni, G., Lincoff, G.H., 1981. Simon \& Schuster's guide to mushrooms, Simon and Schuster.

Pekşen, A., Karaca, G., 2003. Macrofungi of Samsun province. Turk. J. Bot. 27(3), 173-184.

Perevedentseva, L.G., 2011. Edible mushrooms in the Perm Territory forests (Russia). Pol. Sumarstvo. 57(3), 7.

Phillips , R. 2013. Mushrooms: A Comprehensive Guide to Mushroom Identification, Pan Macmillan.

Quimio, T.H., 1982. Tropical Mushrooms: Biological Nature and Cultivation Methods, Chinese University Press.

Ramsbottom, J., 1953. Mushrooms and toadstools. A study of the activities of fungi. Mushrooms and toadstools. A study of the activities of fungi.

Rebello, C.A., Ludescher, R.D., 1998. Influence of tightly bound $\mathrm{Mg}^{2+}$ and $\mathrm{Ca}^{2+}$, nucleotides, and phalloidin on the microsecond torsional flexibility of F-actin. Biochemistry. 37(41), 14529-14538.

Robledo, G.L., Rajchenberg, M., 2007. South American polypores: first annotated checklist from Argentinean Yungas. Mycotaxon, 100, 510.

Ryberg, M., Nilsson, R.H., Kristiansson, E., Töpel, 
M., Jacobsson, S., Larsson, E., 2008. Mining metadata from unidentified ITS sequences in GenBank: a case study in Inocybe (Basidiomycota). BMC Evol. Biol. 8, 50.

Ryvarden, L., Gilbertson, R. L., 1993 . European polypores . Part 1. Synopsis Fungorum, 6, 1-387.

Saba, M., Ahmad, I., Khalid, A.N., 2015. New reports of Inocybe from pine forests in Pakistan. Mycotaxon. 130(3), 671-681.

Saitta, A., Bernicchia, A., Gorjón, S.P., Altobelli, E., Granito, V.M., Losi, C., Lunghini, D., Maggi, O., Medardi, G., Padovan, F., Pecoraro, L., 2011. Biodiversity of wood-decay fungi in Italy. Plant Biosyst. 145(4), 958-968.

Sanmee, R., Tulloss, R.E., Lumyong, P., Dell, B., Lumyong, S., 2008. Studies on Amanita (Basidiomycetes: Amanitaceae) in Northern Thailand. Fungal Divers. 32, 97-123.

Seok, S. J., Kim, Y.S., Hyun, P.S., Hee, M.K., Hee, Y.K., 2000. Taxonomic study on Inocybe in Korea. Mycobiol. 28(3), 149-152.

Sesli, E., Denchev, C. M., 2008. Checklists of the myxomycetes, larger ascomycetes, and larger basidiomycetes in Turkey. Mycotaxon. 106, 65.

Shen, Q., Chen, W., Yan, Z., Xie, Z., 2009. Potential pharmaceutical resources of the Qinling Mountain in central China: Medicinal fungi. Front. Biol. China. 4(1), 89-93.

Sibounnavong, P., Cynthia, C.D., Kalaw, S.P., Reyes, R.G., Soytong, K., 2008. Some species of macrofungi at Puncan, Carranglan, Nueva Ecija in the Philippines. J. Agric. Technol. 4(2), 105-115.

Suay, I., Arenal, F., Asensio, F.J., Basilio, A., Angeles Cabello, M., Teresa Díez, M., García, J.B., González del Val, A., Gorrochategui, J., Hernández, P., Peláez, F., 2000. Screening of basidiomycetes for antimicrobial activities. Antonie van Leeuwenhoek. 78(2), 129-140.

Suliaman, S.Q., Al- Khesraji, T.O., Hassan, A., 2017. New records of basidiomycetous macrofungi from Kurdistan region - Northern Iraq . Afr. J. Plant Sci. 11(6), 209-219.

Sultana, K., Rauf, C.A., Riaz, A., Naz, F., Irshad, G., Haque, M., 2011. Check list of agarics of Kaghan valley-1. Pak. J. Bot. 43(3), 1777-1787.
Sun, H., Zhao, C.G., Tong, X., Qi, Y.P., 2003. A lectin with mycelia differentiation and antiphytovirus activities from the edible mushroom Agrocybe aegerita. Int. J. Biochem Mol. Biol. 36(2), 214-222.

Tedersoo, L., Jairus, T., Horton, B.M., Abarenkov, K., Suvi, T., Saar, I., Kõljalg, U., 2008. Strong host preference of ectomycorrhizal fungi in a Tasmanian wet sclerophyll forest as revealed by DNA barcoding and taxon-specific primers. New Phytol. 180(2), 479-490.

Tel-Çayan, G., Öztürk, M., Duru, M.E., Rehman, M.U., Adhikari, A., Türkoğlu, A., Choudhary, M.I., 2015. Phytochemical investigation, antioxidant and anticholinesterase activities of Ganoderma adspersum. Indust. Crops Prod. 76, 749-754.

Vasco-Palacios, A.M., Franco-Molano, A.E., 2013. Diversity of Colombian macrofungi (Ascomycota-Basidiomycota). Mycotaxon. 121, $1-58$.

Velázquez, J.C., Ruiz-Boyer, A., 2005. Checklist of polypores of Costa Rica. Rev. Mex. Micol. 20, 45-52.

Wang, X., Liu, H., Zhang, J., Li, T., Wang, Y., 2017. Evaluation of heavy metal concentrations of edible wild-grown mushrooms from China. J. Environ. Sci. Health A: Tox. Hazard. Subst. Environ. Eng. Part B. 52(3), 178-183.

Wang, Y., Xu, B., 2014. Distribution of antioxidant activities and total phenolic contents in acetone, ethanol, water and hot water extracts from 20 edible mushrooms via sequential extraction. Austin J. Nutr. Food Sci. 2(1), 5.

Wood, M.G., Stevens, F.A., 2015. California Mushrooms: The Comprehensive Identification Guide. Timber Press.

Zakhary, J. W., Abo-Bakr, T.M., El-Mahdy, A. R., El-Tabey, S.A., 1983. Chemical composition of wild mushrooms collected from Alexandria. Food Chem. 11(1), 31-41.

Zhang, J., Tang, Q., Zhou, C., Jia, W., Da Silva, L., Nguyen, L. D., Reutter, W., Fan, H., 2010. GLIS, a bioactive proteoglycan fraction from Ganoderma lucidum, displays anti-tumour activity by increasing both humoral and cellular immune response. Life Sci. 87(19), 628-637. 
Zhang, P., Chen, Z., Hu, J., Wei, B., Zhang, Z., Hu, W., 2005. Production and characterization of amanitin toxins from a pure culture of Amanita exitialis. FEMS Microbiol. Lett. 252(2), 223228.

Zhang, L.F., Yang, J.B., Yang, Z.L., 2004. Molecular phylogeny of eastern Asian species of Amanita (Agaricales, Basidiomycota): taxonomic and biogeographic implications.
Fungal Divers. 17, 219-238.

Zhao, C., Sun, H., Tong, X., Qi, Y., 2003. An antitumour lectin from the edible mushroom Agrocybe aegerita. Biochem. J. 374, 321.

Zotti, M., Vizzini, A., Traverso, M., Boccardo, F., Pavarino, M., Mariotti, M'G., 2008. The macrofungi checklist of Liguria (Italy): the current status of surveys. Mycotaxon. 105, 167-170.

\section{How to cite this article:}

Al-Khesraji, T.O., Suliaman, S. Q., Hassan, A. A., 2018. First record of fourteen basidiomycetous macrofungi (Agaricomycetes) from Iraq. Int. J. Curr. Res. Biosci. Plant Biol. 5(6), 25-44. doi: https://doi.org/10.20546/ijcrbp.2018.506.003 